\title{
Implications of Long Term Irrigation with Wastewater on The Contents and Retention Kinetics of Potentially Toxic Elements in Typic Torripsamment Soils
}

\author{
M.H.H. Abbas and M.A. Bassouny \\ Soils and Water Department, Faculty of Agriculture, Benha University, Egypt
}

\begin{abstract}
T HE consequences of irrigation with wastewater (rich in organic matter) on the distribution of potentially toxic elements (PTEs) between the soluble and total forms as well as their distribution among the different soil layers of El-Gabal El-Asfar soils was the main target of this work. Eight soil locations were sampled at three different depths to represent different periods of irrigation with wastewater extended beyond 80 years. These samples were analyzed for their contents of SOM, cation exchange capacity (CEC), total and soluble concentrations of PTEs i.e. $\mathrm{Ni}, \mathrm{Pb}, \mathrm{Cd}, \mathrm{Co}, \mathrm{Zn}$ and $\mathrm{Cu}$. Results revealed that both $\mathrm{SOM}$ and $\mathrm{CEC}$ increased steadily and significantly in the uppermost $030-\mathrm{cm}$ layer with ageing. The corresponding increases within the subsequent soil depths seemed to be slight. Soluble and total concentrations of PTEs also increased progressively within the different soil depths with ageing; however, the depthwise increases seemed less obvious. Based on the Dutch system formula, the soil irrigated for a period extended up to 80 years could be considered slightly polluted with Co, moderately polluted with $\mathrm{Pb}$, severely polluted with $\mathrm{Ni}, \mathrm{Cu}$ and $\mathrm{Zn}$ and very severely polluted with $\mathrm{Cd}$. Soluble PTEs concentrations were correlated significantly with their total concentrations in soil and both were correlated significantly with SOM and CEC. The relationships between amounts of retained PTEs and their corresponding soluble concentrations were best fitted to Langmuir isotherm model. The outcome relations between the amounts of retained PTEs and aging were fitted to five kinetic models, the power function and the parabolic diffusion ones seemed to be the best fitting models. In conclusion, although soil organic matter plays important role in distribution of the PTEs between the soluble and retained forms in soil irrigated with wastewater; yet ageing affects this distribution obviously especially in the uppermost soil layer.
\end{abstract}

Keywords: Retention kinetics, El-Gabal El-Asfar, Adsorption isotherms, Soil organic matter, Soil layers

\section{Introduction}

Potentially toxic elements PTEs can be brought to soils from different anthropogenic sources e.g. industrial and agricultural activities (Bolan and Duraisamy, 2003; Abdelhafez et al., 2012), metal smelter (Alloway, 2013), sewage sludge and livestock manures (Nicholson et al., 2003). Once they come in contact with a sandy soil, they become sorbed within the surface layers (Gustafsson et al., 2003) mainly by soil organic matter (Ellen et al., 2008). These elements persist in soils and do not undergo microbial degradation (Greger, 2005). Plants grown on contaminated soils absorb and accumulate PTEs within the different plant parts and this might possess potential health risks for man and animals feeding on these plants (Khan et al., 2008, Ibrahim et al., 2016; Abbas and Abdelhafez,
2014;-Abdelhafez et al., 2015; Ebong et al., 2018). Accordingly, monitoring the level of contaminants in soil periodically is essential to ensure safe environmental and ecological use of this natural resource.

Although, soil organic matter (SOM) plays important roles in increasing soil fertility, especially in low textured soils (Farid et al., 2014), beside of its positive effect on improving soil physical and chemical characteristics (Abdelhafez et al., 2018); yet, successive applications of organic matter can increase the levels of retained PTEs in soils (Guo et al., 2018), especially when soils are irrigated with wastewater for long time periods (Mapanda et al., 2005). In this concern, sorption of PTEs by SOM is thought to be 613-fold higher than that occurred on soil mineral surfaces (Lair et al.,

*Corresponding author: Mohamed.abbas@fagr.bu.edu.eg 
2007). Probably, the functional groups of soil organic matter account for specific adsorption of PTEs from soil solution (Wang et al., 2017; Wen et al., 2018); thus, reduce their mobility and phytotoxicity to the grown plants (Ciavatta et al., 1993; Clemente et al., 2006; Peng et al., 2009; Diagboya et al., 2015). On the other hand, these metals can be released again to the soil solution upon organic matter decomposition (Yue et al., 2017). Also, the fraction of the organic matter which dissolves in water can form soluble organo-metal complexes (Weng et al., 2002; Ren et al., 2015; Kunhikrishnan et al., 2017). Moreover, dissolved organic carbon can block the binding sites and this might in turn reduce further sorptivity of PTEs by soil (Refaey et al., 2017). Thus, light textured contaminated arid soils of low $\mathrm{CaCO}_{3}$ content probably exhibit low affinity for PTEs retention.

In Egypt, 1,250 hectares at El-Gabal ElAsfar Farm are irrigated with wastewater (Abo el Abas, 2004) for a period extended over 80 years (Elgala et al., 2003). Successive irrigations with wastewater raised significantly the level of PTEs in soils (El-Motaium et al., 2009) and; at the same time, added appreciable amounts of organic matter to the irrigated soil ( $\mathrm{Su}$ et al., 2010). This farm is located within the arid zone area and its soils are characterized by light texture (low in their silt and clay contents) (El-Hassanin et al., 1993). Therefore, the rate of decomposintion of soil organic matter at this arid zone area is high (Rodeghiero et al., 2009). In spite of that the soluble contents of PTEs in such soils are extremely low and did not exceed $5 \%$ of the total contents (Zaghlol et al., 2006). The mechanism of changing PTEs from a form to another seems to be not clearly documented. To what extent can SOM reduce the mobility and phytotoxicity of PTEs in a Typic Torripsamment soil irrigated with wastewater (rich in organic materials) for a period extended up to 80 years or more was the question upon which the current study tried to answer. Therefore, this investigation took into account the soluble and total concentrations of these metal ions within the different soil layers in a trial to through some light on the mechanism of PTEs sorption within the surface and subsurface soil layers since the mechanisms of PTEs sorption within the subsurface soil layers are not well identified according to Tiberg et al. (2018). Moreover, the kinetics of PTEs retained within the different soil layers were considered to identify the slowest step affecting the immobilization of PTEs under field conditions rather than the laboratory ones. Changes in SOM and consequently CEC of soil with ageing will be a matter of concern in this study to explore, to what extent; these variables might affect the amounts of the soluble and total contents of PTEs in soils.

\section{Materials and Methods}

Study Site

The current study was conducted on the soils of El-Gabal El-Asfar farm. This farm is located about $25 \mathrm{~km}$ northeast of Cairo governorate (Elbana et al., 2013) between longitude $31^{\circ} 22^{\prime}$ $00^{\prime \prime} \mathrm{E}$; latitude $30^{\circ} 12^{\prime} 00^{\prime \prime} \mathrm{N}$, at 15 meters above sea level (Abdel-Shafy and Abdel-Sabour, 2006). The climate of the study area is arid where the average temperature is from $13{ }^{\circ} \mathrm{C}$ (in January) to $28^{\circ} \mathrm{C}$ (in June), total rainfall is as low as $25 \mathrm{~mm}$ $\mathrm{yr}^{-1}$ and the annual evapotranspiration rate is high i.e. 1,600 mm (Abo el Abas, 2004). Mean annual relative humidity is $49 \%$ and average annual wind speed is $20 \mathrm{~km} \mathrm{~h}^{-1}$. Direction of wind is generally north east. Irrigation of soils of this farm is mainly surface with wastewater. Main properties of the wastewater are shown in Table 1. According to

TABLE 1. Main properties of the wastewater used for irrigation of El-Gabal El-Asfar soils

\begin{tabular}{lcc|ccc}
\hline Property & Unit & Value & Properties & Unit & Value \\
\hline $\mathrm{pH}$ & - & 8.12 & $\mathrm{Zn}$ & $\mathrm{mg} \mathrm{L}^{-1}$ & 1.78 \\
$\mathrm{EC}$ & $\mathrm{dS} \mathrm{m}$ & $\mathrm{mg} \mathrm{L}$ & 0.169 \\
$\mathrm{TDS}$ & 1.52 & 972.80 & $\mathrm{Cb}$ & $\mathrm{mg} \mathrm{L}^{-1}$ & 0.39 \\
$\mathrm{TH}$ & $\mathrm{mg} \mathrm{L}^{-1}$ & 368.50 & $\mathrm{Co}$ & $\mathrm{mg} \mathrm{L}^{-1}$ & 0.17 \\
$\mathrm{SAR}$ & - & $\mathrm{Cd}$ & $\mathrm{mg} \mathrm{L}^{-1}$ & 0.02 \\
Mg ratio & $\mathrm{mg} \mathrm{L}^{-1}$ & $\mathrm{Ni}$ & $\mathrm{mgC} \mathrm{L}^{-1}$ & 0.18 \\
COD & $\mathrm{mgO}_{2} \mathrm{~L}^{-1}$ & 450.00 & $\mathrm{DOC}$ & & 195.00 \\
BOD & $\mathrm{mgO}_{2} \mathrm{~L}^{-1}$ & 262.00 & & & \\
\hline
\end{tabular}

Note: EC is the electric conductivity, TDS is the total dissolved solids, TH is the total hardness, SAR is the sodium adsorption ration, $\mathrm{COD}$ is the chemical oxygen demand, BOD is the biological oxygen demand and DOC is the dissolved organic carbon.

Egypt. J. Soil Sci. 58, No. 3 ( 2018 ) 
Ayers and Westcot (1994), Co and Cd exceeded the permissible levels which are 0.05 and 0.01 , respectively, whereas, $\mathrm{Zn}, \mathrm{Cu}, \mathrm{Pb}$ and $\mathrm{Ni}$ were within the acceptable levels in water $(2,0.2,0.5$ and 0.2 , respectively).

\section{Soil sampling}

Eight locations were selected from ElGabal El-As far area to comprise 0, 5, 10, 15, $25,40,60$ and 80 years of the cropping history (Fig 1).
Soil samples were collected from each location at three different depths, i.e. 0-30, 30-60 and 60$120 \mathrm{~cm}$, air dried, cursed, sieved to pass through a $2 \mathrm{~mm}$ sieve and analyzed for their chemical characteristics as well as particle size distribution as outlined by Sparks et al. (1996) and Klute (1986) (Table 2)

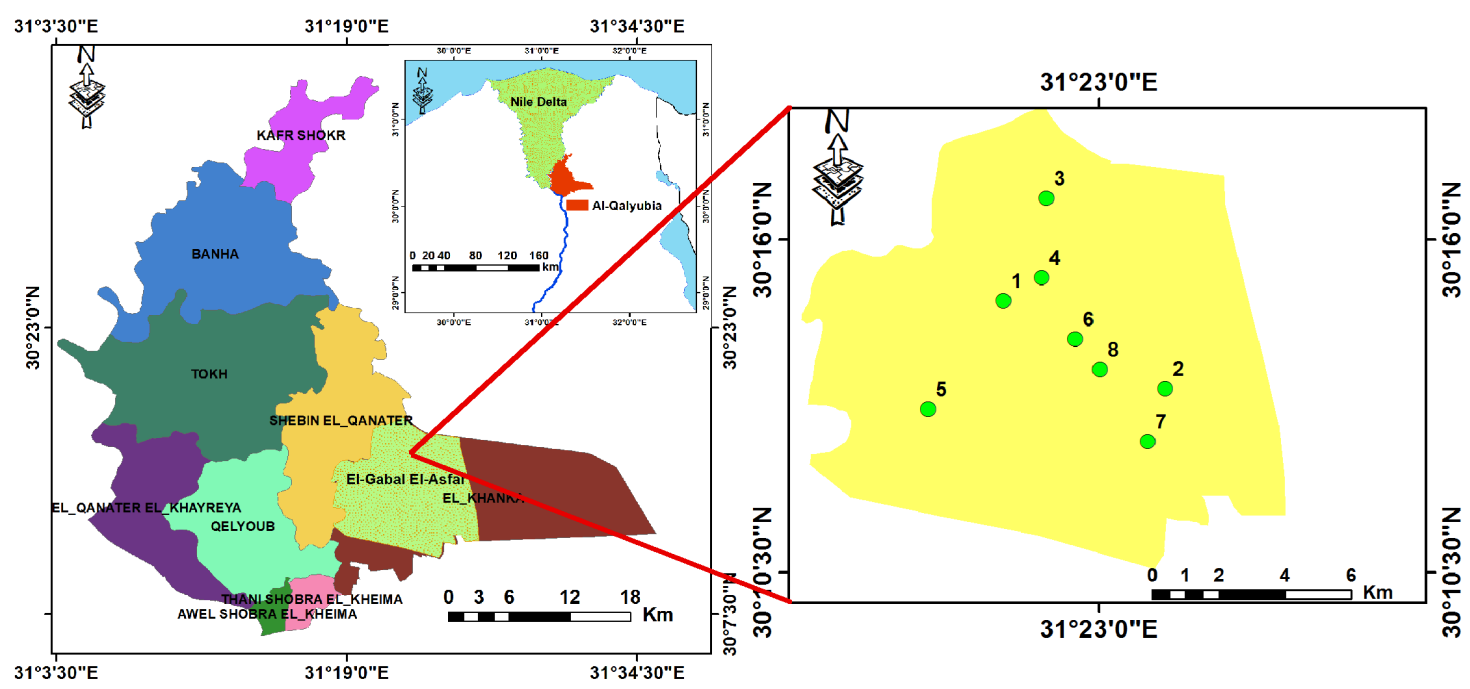

Fig. 1. Location map of the studied sites (numbers from 1 to 8 corresponding to $0,5,10,15,25,40,60$ and 80 years cropping period .

TABLE 2. Chemical properties and particle size distribution of the soil surface layer $(0-30 \mathrm{~cm})$ of the studied locations

\begin{tabular}{|c|c|c|c|c|c|c|c|c|c|}
\hline Soil location & & L1 & L2 & L3 & L4 & L5 & L6 & L7 & L8 \\
\hline Cropping period & years & $\mathbf{0}$ & 5 & 10 & 15 & 25 & 40 & 60 & 80 \\
\hline $\mathrm{pH}^{*}$ & - & 7.63 & 7.34 & 7.23 & 7.17 & 7.01 & 6.83 & 6.69 & 6.53 \\
\hline $\mathrm{EC}^{* *}$ & $\mathrm{dS} \mathrm{m}^{-1}$ & 2.8 & 2.7 & 2.5 & 2.3 & 2.1 & 2.1 & 2.0 & 2.0 \\
\hline $\mathrm{OM}$ & $\mathrm{g} \mathrm{kg}^{-1}$ & 0.78 & 7.45 & 12.56 & 33.75 & 39.76 & 41.55 & 48.67 & 53.12 \\
\hline $\mathrm{CaCO}_{3}$ & $\mathrm{~g} \mathrm{~kg}^{-1}$ & 2.65 & 2.57 & 2.48 & 2.34 & 2.31 & 2.13 & 2.11 & 1.12 \\
\hline CEC & $\mathrm{cmol}_{\mathrm{c}} \mathrm{kg}^{-1}$ & 7.71 & 7.76 & 7.85 & 15.54 & 20.12 & 31.23 & 35.65 & 37.43 \\
\hline Sand & $\%$ & 96.3 & 95.2 & 94.1 & 92.2 & 90.7 & 88.9 & 87.3 & 86.5 \\
\hline Silt & $\%$ & 2.6 & 2.76 & 2.4 & 3.6 & 4.7 & 5.8 & 6.4 & 7.1 \\
\hline Clay & $\%$ & 1.1 & 2.04 & 3.5 & 4.2 & 4.6 & 5.3 & 6.3 & 6.4 \\
\hline Texture & (USDA) & Sand & Sand & Sand & Sand & Sand & Sand & $\begin{array}{c}\text { Loamy } \\
\text { sand }\end{array}$ & $\begin{array}{c}\text { Loamy } \\
\text { sand }\end{array}$ \\
\hline
\end{tabular}

Note: ${ }^{*} \mathrm{pH}:$ in 1:2.5 soil: water suspension; ${ }^{* *} \mathrm{EC}$ : in saturated paste extract; L: location 
Soil portions of the eight sampled locations at the three successive soil layers were analyzed for their soluble contents of $\mathrm{Pb}, \mathrm{Ni}, \mathrm{Cd}, \mathrm{Co}, \mathrm{Zn}$ and $\mathrm{Cu}$ after being extracted with deionized water (1:15 soil: water) for two hours according to Aikpokpodion (2013). Corresponding soil portions were digested using a tri-acid mixture (HNO3:H2SO4:HClO4, 10:4:1) according to Sahrawat et al. (2002), filtered through 0.45 um-pore-diameter filter and acidified with nitric acid $\mathrm{pH}<2$. Both the total and soluble contents of PTEs were determined using Inductively Coupled Plasma Optical Emission Spectrometer (ICP-OES) Model PERKIN ELMER Optima 3000. Soil organic matter (SOM) was determined using the modified Walkley and Black method (Nelson and Sommers, 1996). Cation exchange capacity (CEC) was determined using ammonium acetate method according to Roweli (1994). All chemicals used in this study were of analytical grade reagent.

Zero order $\left(Q_{t}-Q_{0}-k_{0}{ }^{t}\right)$ Eq 1

First order $\left(\ln Q_{t}=\ln Q_{0}-k_{i} t\right)$ Eq. 2

Power function $\left(Q,=a t^{b}\right)$ Eq. 3

Simple Elovich $\left(Q_{t}=1 / \beta \ln (\alpha \beta)+(1 / \beta) \ln t\right)$ Eq. 4

Parabolic diffusion $\left(Q_{1}=Q_{\mathrm{n}}+K_{n} t^{1 / 3}\right)$.
Data analyses

obtained data were statistically analyzed analysis of variance (ANOVA) and Dunken Test at 0.05 probability level. The reference levels of PTEs in soil were calculated according to the Dutch system formula as mentioned by Lacatusu (2000) as follows: $\mathrm{Ni}(10+\mathrm{A}), \mathrm{Pb}(50+\mathrm{A}+\mathrm{MO})$, $\mathrm{Cd}\left(0.4+0.007\left(\mathrm{~A}^{*}+3 \mathrm{MO}^{* *}\right), \mathrm{Co}(20), \mathrm{Zn}(50+\right.$ $1.5(2 \mathrm{~A}+\mathrm{MO})), \mathrm{Cu}(150.6+(\mathrm{A}+\mathrm{MO})$, where $\mathrm{A}$ is the clay content $(\%)$ and $\mathrm{MO}$ is the organic matter content $(\%)$ in soil. The concentrations of retained soluble concentrations of PTEs from the ding total contents and then the retained graphically versus the period of cultivation and kinetic models as mentioned by Sparks (1999) and used by Reyhanitabar and Gilkes (2010) and Abbas and Salem (2011): PTEs in soil were calculated by subtracting
The used symbols $Q_{t}$ and $Q_{0}$ refer to the retained values of PTEs calculated at time $t$ (hour) and at $\mathrm{t}=$ zero, respectively. The standard error of estimation (S.E.) was calculated according to Reyhanitabar and Gilkes (2010) and Abbas (2013) as follows:

$$
S E=\left[\sum\left(Q_{\mathrm{r}}-Q_{i}{ }^{2}\right)^{2} /(n-2)\right]^{1 / 2}, \quad \mathrm{Eq} 6
$$

Lincar model $Q=k_{p} C$

Langmuir isotherm $Q=\frac{a b c}{1+b c}$

Van Bemmelen- Freundlich $Q=k C^{\frac{1}{n}}$

Egypt. J. Soil Sci. 58, No. 3 ( 2018 ) predicted amounts of sorbed PTEs obtained at time $\mathrm{t}$, respectively, and $\mathrm{n}$ is the number of measurements.

Retained heavy metals were calculated by subtracting the soluble concentrations of PTEs from the total contents in soil, plotted graphically versus the soluble concentrations of these metal ions in soil and then the obtained relations were fitted to the following adsorption isotherm models as described by Sposito (2008) and Loffredo and Senesi (2006).

$$
\begin{aligned}
& \text { Eq. } 7 \\
& \text { Fq. } 8 \\
& \text { Eq. } 9
\end{aligned}
$$

Where $Q_{t}{ }^{t}$ and $Q_{t}{ }^{t}$ are the measured and 


\section{$\underline{\text { Results and Discussion }}$}

Soil organic matter (SOM) and CEC in Typic Torripsamment soil as affected by successive irrigations with wastewater

Results shown in Fig. 2 reveal that SOM content increased steadily and significantly with ageing within the uppermost $030-\mathrm{cm}$ layer. On the other hand, such increases seemed to be slight and insignificant within the subsequent soil layers with ageing until 60 years beyond which significant increases occurred. The decrease in the organic matter content in soil with depth was also observed by Jobbágy and Jackson (2000). Concurrent increases in soil CEC were also recorded within the top 030- $\mathrm{cm}$ layer; however, these increases seemed to be significant only after 15 years ageing. The slight increases in soil CEC within the first 10 years of cultivation probably occurred due to a corresponding slight variation in SOM within the same period. This finding supports a previous one attained by Machmuller et al. (2015) who showed that soil CEC increased significantly with the increase in soil organic matter content.

\section{Soluble PTEs in Typic Torripsamment as affected by ageing}

Figure 3 reveals that the concentrations of soluble PTEs increased progressively within the different soil layers with ageing; however, these concentrations did not exceed $8 \%$ of the corresponding total contents. Concentrations of soluble $\mathrm{Ni}, \mathrm{Pb}, \mathrm{Zn}, \mathrm{Cu}, \mathrm{Cd}$ and $\mathrm{Co}$ within the uppermost $0-30 \mathrm{~cm}$ layer of the soil, irrigated with sewage water for 80 years, were $9.02,11.13,31.52,16.40,10.39,44.50$ fold higher than those of the control one (zero time cropping), respectively. The solubility
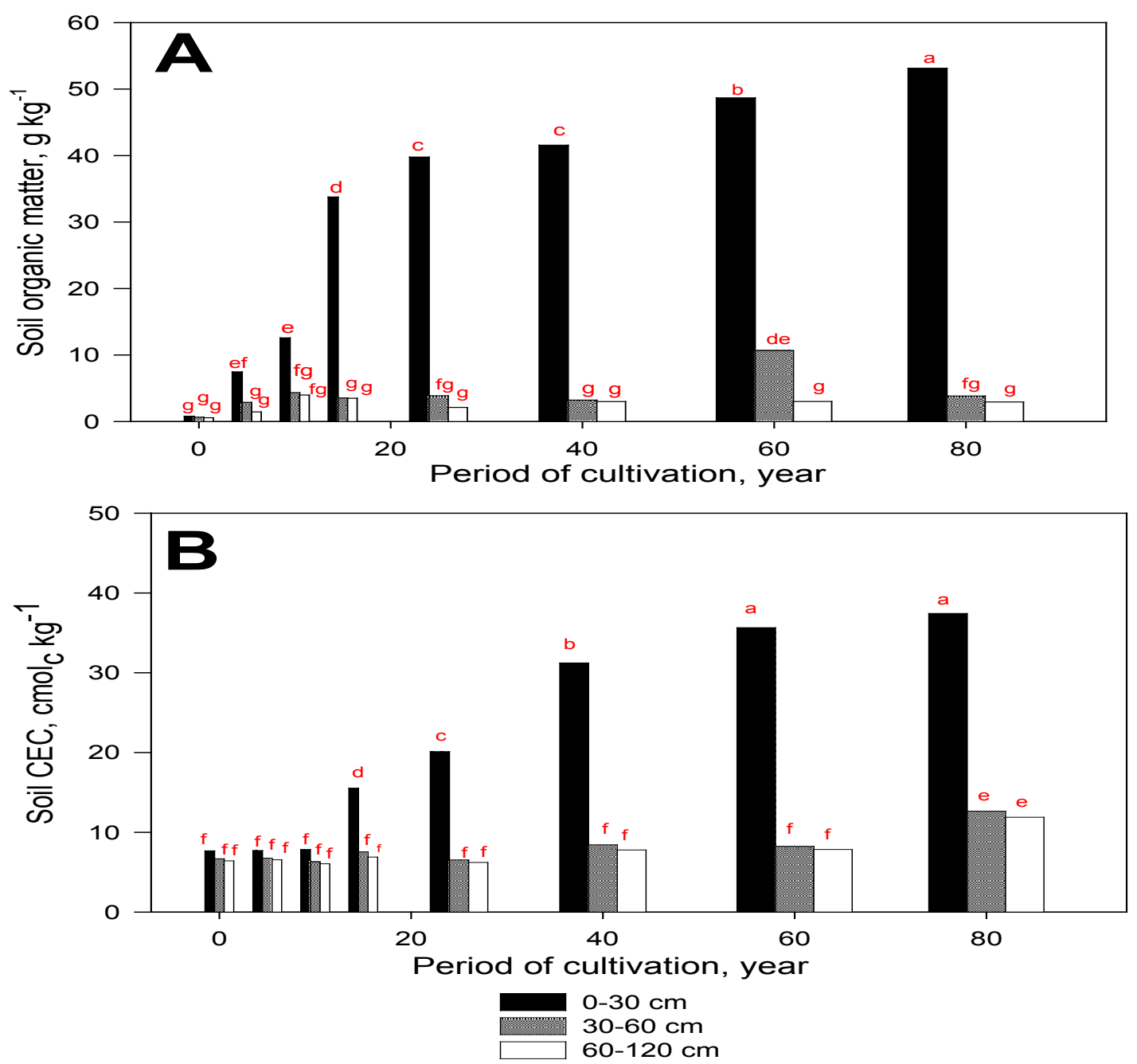

Fig. 2. Effect of ageing on soil organic matter (SOM) and CEC in Typic Torripsamment soil irrigated with wastewater 
of PTEs in deeper soil layers also increased with ageing, but with a relatively lower trend. The successive irrigations and the different agricultural practices might account for the transfer of pollutants to deeper soil layers (Hashim et al., 2017). Also, SOM can chelate PTEs forming relatively soluble organometallic complexes (Kalbitz and Wennrich, 1998; Almås, 2000; Ren et al., 2015) and these complexes increase the mobility of heavy metals in soil (Ashworth and Alloway, 2008; Rikta et al., 2018). The reductions occurred in soil $\mathrm{pH}$ owing to organic matter decomposition (Abdelhafez et al., 2018), might, in turn, increase the solubility of minerals bearing heavy metals in soil (Blume and Brümmer, 1991). On the other hand, the low oluble content of lead within $60-120 \mathrm{~cm}$ soil layer might be attributed to formation of relatively stable complexes with the organic
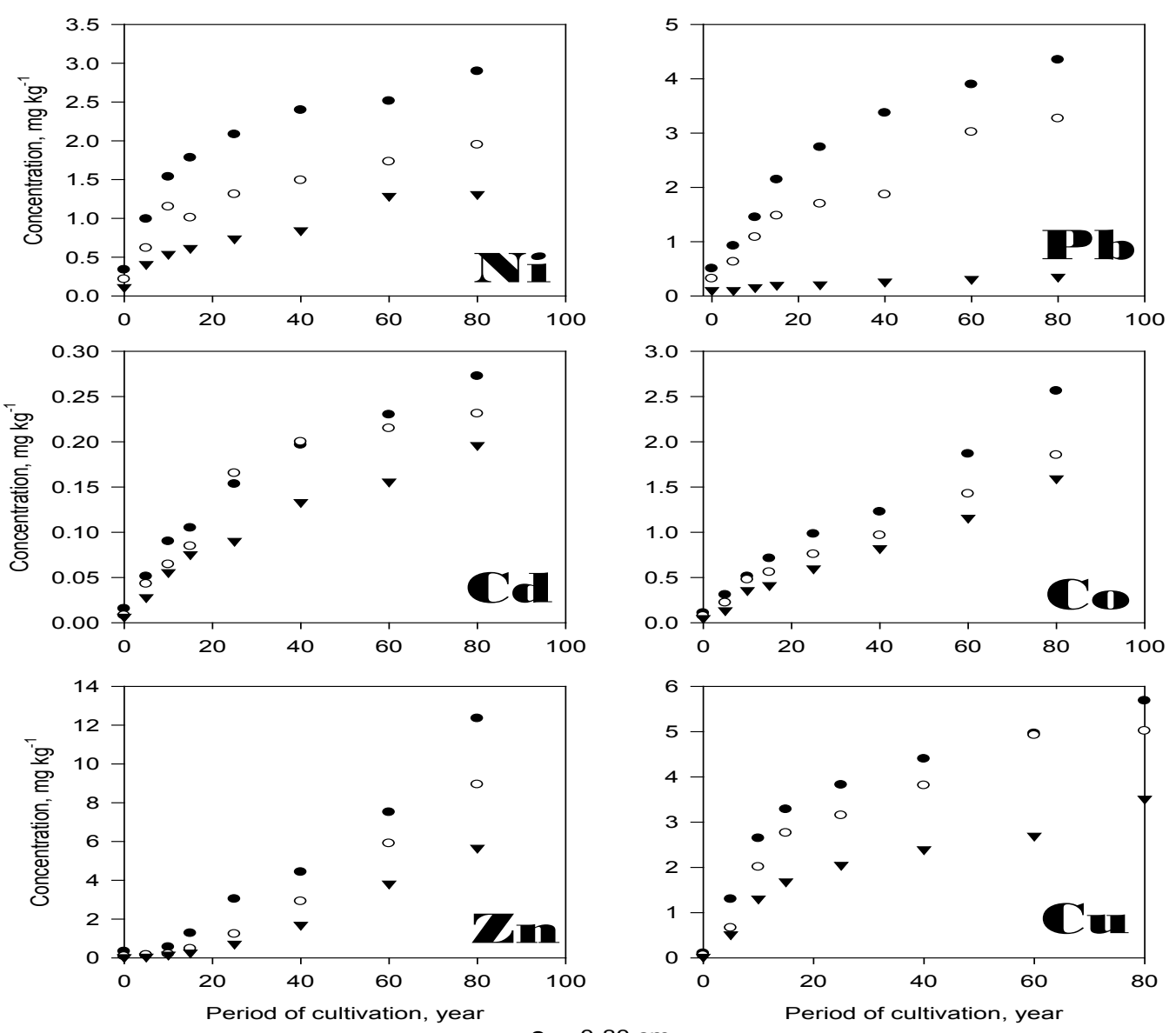

$0-30 \mathrm{~cm}$

$30-60 \mathrm{~cm}$
$60-120 \mathrm{~cm}$

Fig. 3. Effect of ageing on concentrations of soluble PTEs in the different soil layers of the Typic Torriorthent soil $(0-30 \mathrm{~cm}(\bullet), 30-60 \mathrm{~cm}(\mathrm{)})$ and $60-120 \mathrm{~cm}(\nabla))$

Egypt. J. Soil Sci. 58, No. 3 ( 2018 )

components; hence its mobility and desorption seemed to be relatively low (Strawn et al., 2000). The increase in concentrations of soluble PTEs fraction probably account for corresponding increases in total PTEs in soil with ageing.

Total contents of PTEs in the Typic Torripsamment soil as affected by ageing

Total concentrations of the investigated PTEs increased markedly within the different soil layers owing to the successive irrigations with wastewater (Fig 4). Total concentrations of $\mathrm{Pb}$ and $\mathrm{Zn}$, within the different soil segments after 15 years of ageing, exceeded the permissible levels recommended by KabataPendias and Pendias (2001), in the agricultural soils of Austria (100 mg Pb kg-1 and $300 \mathrm{mg}$ $\mathrm{Zn} \mathrm{kg}^{-1}$ ), Likewise, the concentrations of total $\mathrm{Ni}$ and $\mathrm{Cu}$ within the surface $0-30 \mathrm{~cm}$ layer after 80 years of ageing exceeded their 
permissible levels recommended by KabataPendias and Pendias (2001) (i.e. $100 \mathrm{mg} \mathrm{Ni}$ $\mathrm{kg}^{-1}$ and $100 \mathrm{mg} \mathrm{Cu} \mathrm{kg}{ }^{-1}$ ). On the other hand, the concentrations of both $\mathrm{Cd}$ and $\mathrm{Co}$ were within the permissible levels $\left(5 \mathrm{mg} \mathrm{Cd} \mathrm{kg}{ }^{-1}\right.$ and $50 \mathrm{mg} \mathrm{Co} \mathrm{kg}^{-1}$, respectively); however, attention should be paid towards the potentially continuous increase in concentrations of these elements with ageing. Therefore, the ecological evaluations of El-Gabal El-Asfar project should take into account the present and the future concentrations of the potentially toxic elements in soil due to the pronounced effect of ageing on these PTEs.
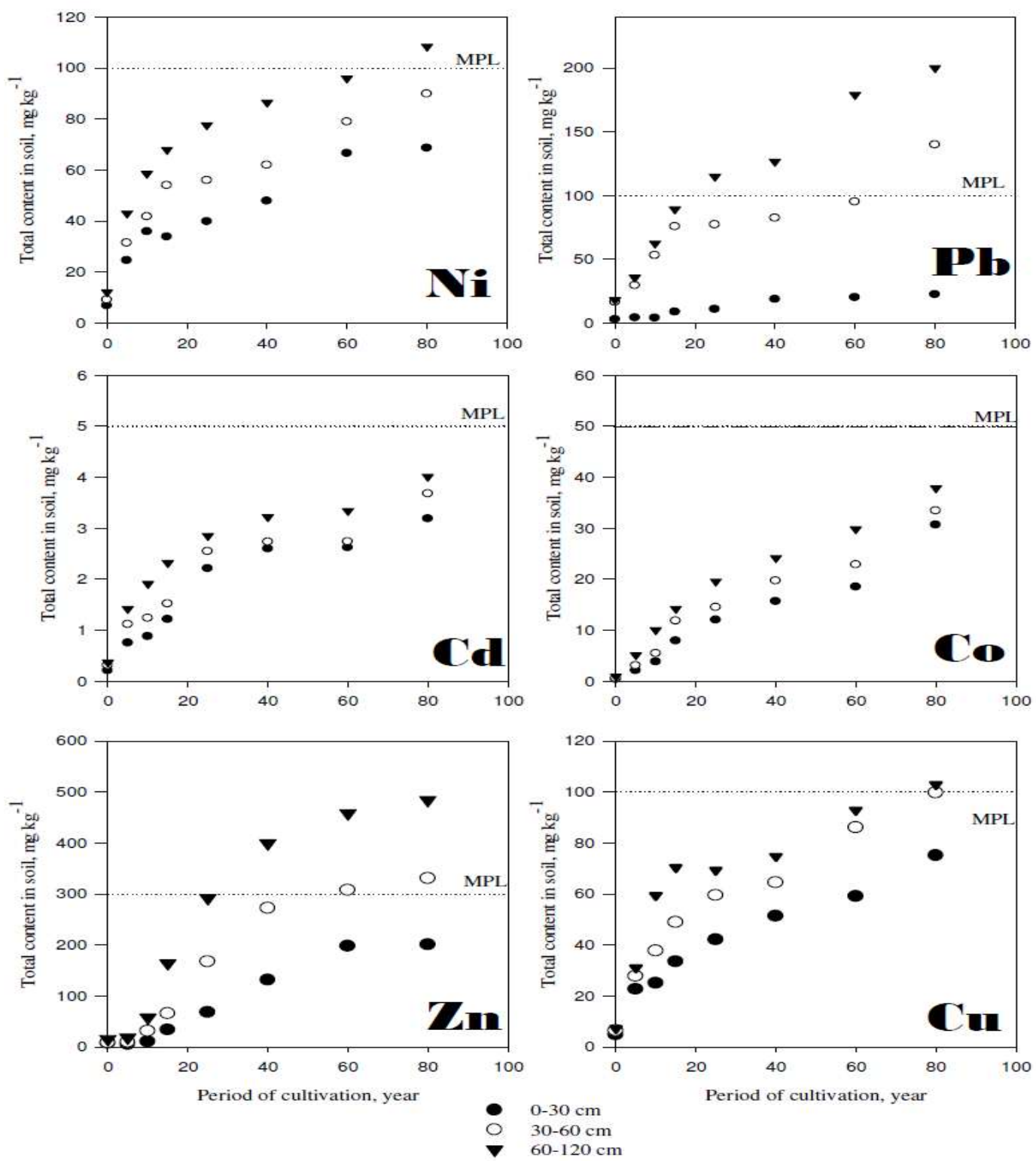

Fig 4. Total concentrations of heavy metals in the different soil layers of the Typic Torriorthent soil $(0-30 \mathrm{~cm}(\bullet)$, $30-60 \mathrm{~cm}(\mathrm{)})$ and $60-120 \mathrm{~cm}(\nabla))$. (MPL: maximum permissible levels adapted from Kabata-Pendias and Pendias, 2001)

Egypt. J. Soil Sci. 58, No. 3 ( 2018)
Based on the Dutch system formula, the metal pollution index was calculated to investigate the increases that occurred in PTEs in soil with ageing as ratios to their natural background levels (A-value) adapted from Lacatusu (2000). Contamination/pollution indexes were evaluated then presented graphically versus ageing (Fig 5). Results show that the investigated soils were slightly polluted with Co, moderately polluted with $\mathrm{Pb}$, severely polluted with $\mathrm{Ni}, \mathrm{Cu}$ and $\mathrm{Zn}$ and very severely polluted with $\mathrm{Cd}$. 


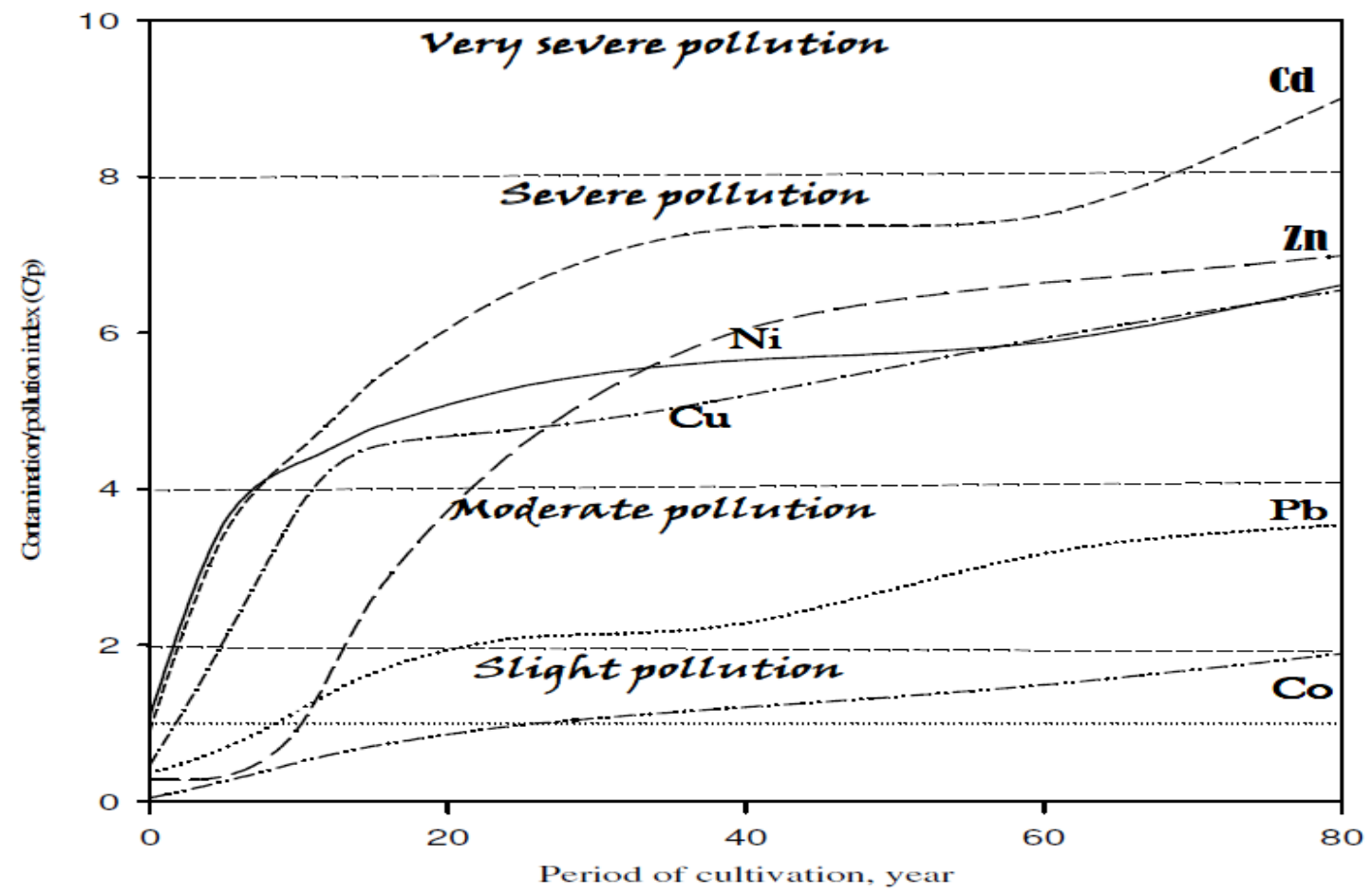

Fig. 5. Interpretation of contamination/pollution of heavy metals in a Typic Torripsamment soil (Based on the Dutch system formula, adapted from Lacatusu 2000)

Description of PTEs retention by Typic Torriorthent soil

Soluble PTEs were plotted graphically versus the corresponding retained concentrations of these metals in soil (Figs 6 and 7) and the obtained relations were fitted to three isotherm models, i.e. the linear, Langmuir and Freundlich ones. The calculated parameters as well as the " $\mathrm{r}$ " " values are recorded in Table 3 . Based on the highest " $r$ " values. Langmuir isotherm seemed to be the best model fitting the retention of $\mathrm{Pb}, \mathrm{Zn}, \mathrm{Co}$, and $\mathrm{Cd}$ within the different layers of the Typic Torriorthent soil which means that the retention process can be considered as adsorption. This model assumes that the thickness of the adsorbed PTEs is only one molecule (Chen, 2015). On the other hand, the retention of $\mathrm{Ni}$ and $\mathrm{Cu}$ within the subsequent

$$
\begin{aligned}
& \mathrm{Pb}^{2+}+\mathrm{CO}_{2}(\mathrm{~g})+\mathrm{H}_{2} \mathrm{O} \leftrightarrow \mathrm{PbCO}_{3} \text { (cerussite) }+2 \mathrm{H}^{+} \\
& \mathrm{Zn}^{2+}+\mathrm{CO}_{2}(\mathrm{~g})+\mathrm{H}_{2} \mathrm{O} \leftrightarrow \mathrm{ZnCO}_{3} \text { (smithsonite) }+2 \mathrm{H}^{+} \\
& \mathrm{Cd}^{2+}+\mathrm{CO}_{2}(\mathrm{~g})+\mathrm{H}_{2} \mathrm{O} \leftrightarrow \mathrm{CdCO}_{3} \text { (octavite) }+2 \mathrm{H}^{+} \\
& \mathrm{Cu}^{2+}+\mathrm{CO}_{2}(\mathrm{~g})+\mathrm{H}_{2} \mathrm{O} \leftrightarrow \mathrm{CuCO}_{3} \text { (malachite) }+2 \mathrm{H}^{+}
\end{aligned}
$$

soil layers seemed to follow a linear model. Although, the different functional groups of the organic molecules, added to the soils, might account for heterogeneous site sorptivity of PTEs (Zhou and Haynes, 2010); yet, this study illustrates that the long term sorptivity of PTEs in soil seemed to exist in the form of monolayer of adsorbed molecules. Probably, organic matter decreases the soluble and exchangeable forms of PTEs while increases the non-exchangeable ones (Mohamed et al., 2018). This might take place because of the transformation of PTEs within the organic fractions (Han and Banin, 1999). Moreover, the released $\mathrm{CO} 2$, upon decomposition of soil organic matter (Lehmann and Kleber, 2015), dissolved in the soil solution forming insoluble carbonate salts of PTEs according to the equations adapted from Lindsay (1991)

$$
\begin{array}{r}
\log \mathrm{k} 0=-4.65 \\
\log \mathrm{K} 0=-7.91 \\
\log \mathrm{K} 0=-6.16 \\
\log \mathrm{K} 0=-12.99
\end{array}
$$




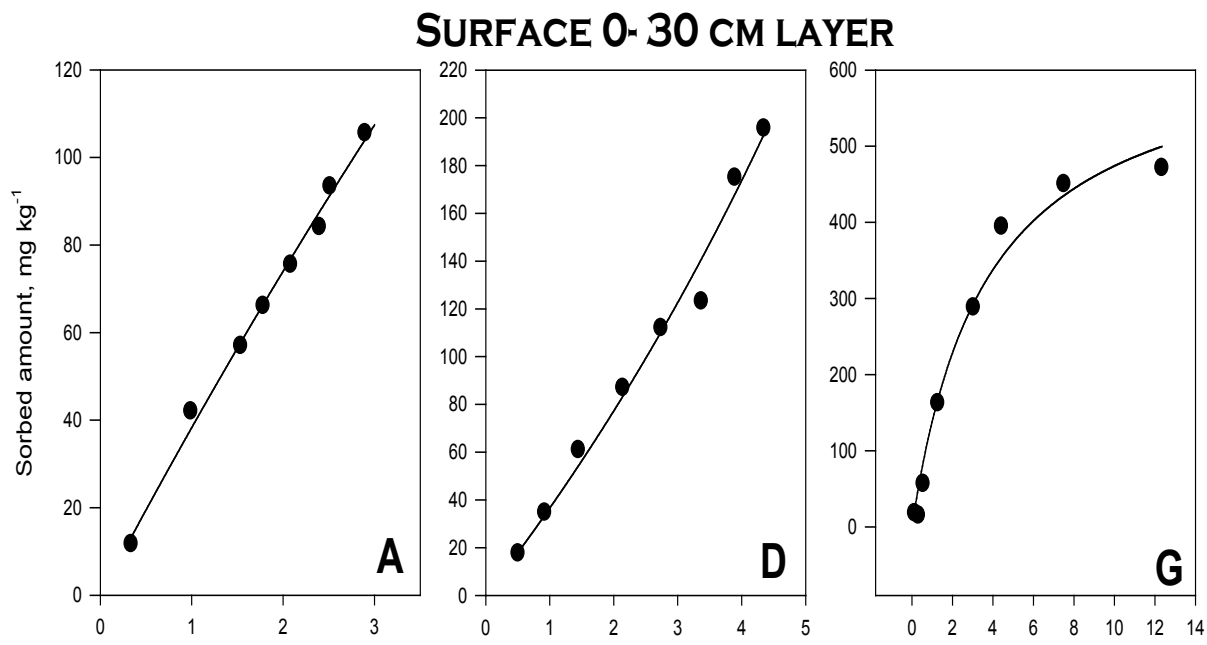

SUB-SURFACE 30. 60 CM LAYER

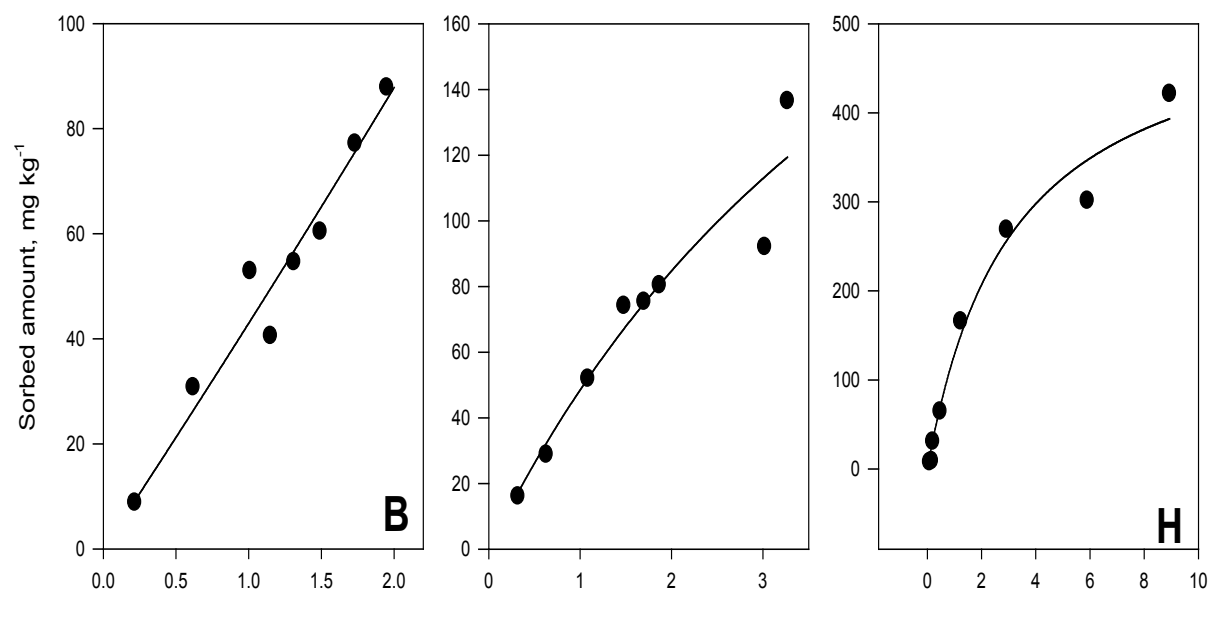

SUB-SURFACE 60-120 CM LAYER

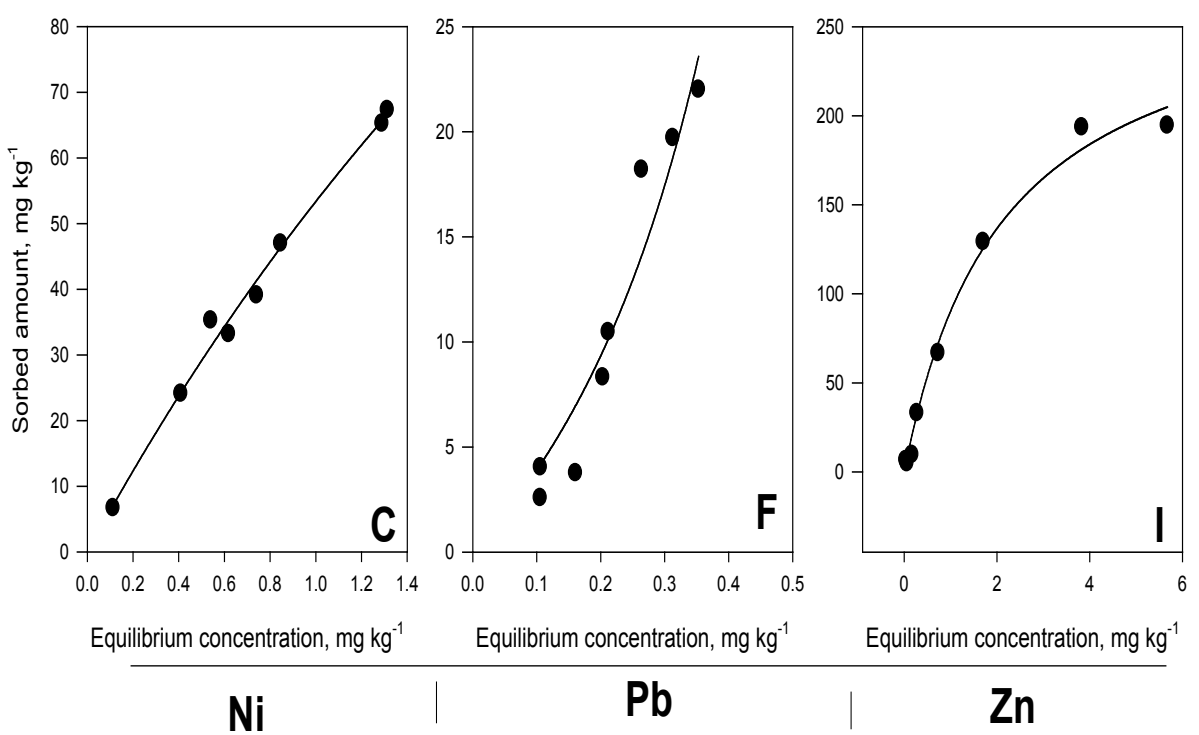

Fig. 6. Sorption of $\mathrm{Ni}, \mathrm{Pb}$ and $\mathrm{Zn}$ on Typic Torriorthent soil as affected by their equilibrium concentrations 


\section{SURFACE 0-30 CM LAYER}
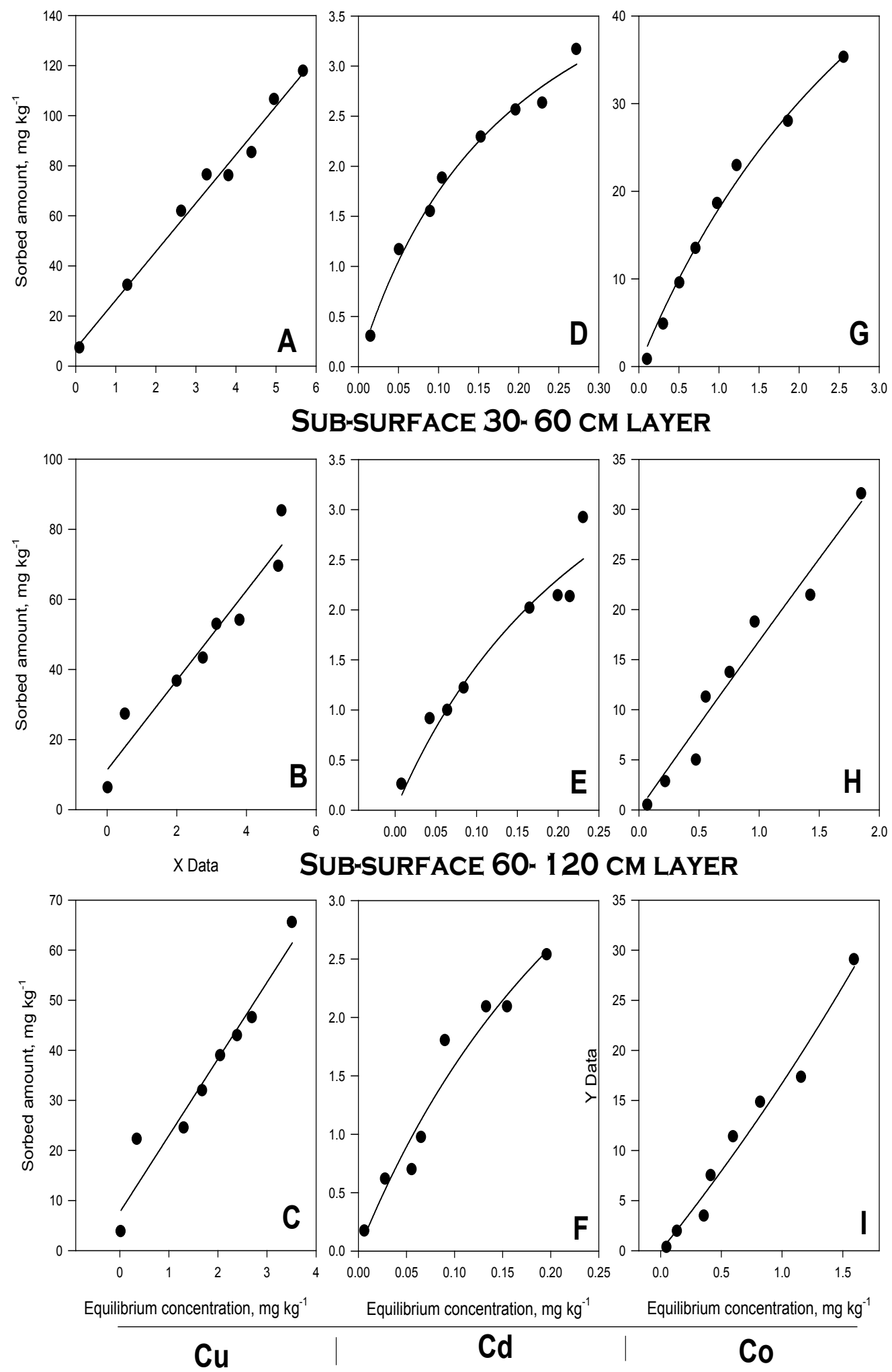

Fig. 7. Sorption of $\mathrm{Cu}, \mathrm{Cd}$ and $\mathrm{Co}$ on Typic Torriorthent soil as affected by their equilibrium concentrations 
TABLE 3. Calculated parameters and " $r$ " values for the investigated adsorption isotherm models

\begin{tabular}{|c|c|c|c|c|c|c|c|c|c|}
\hline & & \multicolumn{2}{|c|}{ Linear } & \multicolumn{3}{|c|}{ Langmuir } & \multicolumn{3}{|c|}{ Van Bemmelen-Freundlich } \\
\hline \multirow{3}{*}{$\mathrm{Ni}$} & & $\mathrm{K}_{\mathrm{d}}$ & $\mathrm{r}^{2}$ & $\mathrm{a}$ & $\mathrm{b}$ & $\mathrm{r}^{2}$ & $\mathrm{k}$ & $1 / \mathrm{n}$ & $\mathrm{r}^{2}$ \\
\hline & $0-30 \mathrm{~cm}$ & 35.44 & 0.993 & 39.66 & 0.04 & 0.994 & 38.58 & 0.936 & 0.994 \\
\hline & $30-60 \mathrm{~cm}$ & 42.95 & 0.995 & 42.05 & 0.02 & 0.950 & 4353 & 0.997 & 0.949 \\
\hline \multirow{3}{*}{$\mathrm{Pb}$} & $60-120 \mathrm{~cm}$ & 48.53 & 0.986 & 64.07 & 0.20 & 0.991 & 52.92 & 0.860 & 0.990 \\
\hline & $0-30 \mathrm{~cm}$ & 44.69 & 0.980 & 34.76 & 0.05 & 0.985 & 35.97 & 1.132 & 0.982 \\
\hline & $30-60 \mathrm{~cm}$ & 34.25 & 0.904 & 56.67 & 0.17 & 0.919 & 48.41 & 0.775 & 0.916 \\
\hline \multirow{3}{*}{$\mathrm{Zn}$} & $60-120 \mathrm{~cm}$ & 13.50 & 0.871 & 20.54 & 0.32 & 0.912 & 15.21 & 0.813 & 0.886 \\
\hline & $0-30 \mathrm{~cm}$ & 39.95 & 0.789 & 176.30 & 0.27 & 0.981 & 144.90 & 0.521 & 0.921 \\
\hline & $30-60 \mathrm{~cm}$ & 45.18 & 0.898 & 169.50 & 0.32 & 0.979 & 121.10 & 0.569 & 0.965 \\
\hline \multirow{4}{*}{$\mathrm{Cu}$} & $60-120 \mathrm{~cm}$ & 36.49 & 0.8814 & 133.10 & 0.47 & 0.991 & 80.82 & 0.566 & 0960 \\
\hline & $0-30 \mathrm{~cm}$ & 19.37 & 0.986 & 24.67 & 0.04 & 0.982 & 25.94 & 0.858 & 0.984 \\
\hline & $30-60 \mathrm{~cm}$ & 12.78 & 0.933 & 21.18 & 0.08 & 0.880 & 25.41 & 0.653 & 0.909 \\
\hline & $60-120 \mathrm{~cm}$ & 11.53 & 0.920 & 21.55 & 0.06 & 0.892 & 23.89 & 0.722 & 0.915 \\
\hline \multirow[t]{2}{*}{$\mathrm{Cd}$} & $0-30 \mathrm{~cm}$ & 9.947 & 0.938 & 26.30 & 5.05 & 0.987 & 6.985 & 0.619 & 0.979 \\
\hline & $30-60 \mathrm{~cm}$ & 9.77 & 0.947 & 19.16 & 3.31 & 0.939 & 7.094 & 0.702 & 0.949 \\
\hline \multirow{4}{*}{$\mathrm{Co}$} & $60-120 \mathrm{~cm}$ & 12.75 & 0.935 & 20.36 & 2.83 & 0.951 & 9.376 & 0.783 & 0.946 \\
\hline & $0-30 \mathrm{~cm}$ & 13.88 & 0.958 & 22.37 & 0.24 & 0.990 & 17.35 & 0.788 & 0.980 \\
\hline & $30-60 \mathrm{~cm}$ & 17.11 & 0.964 & 17.16 & 0.09 & 0.964 & 16.75 & 0.997 & 0.963 \\
\hline & $60-120 \mathrm{~cm}$ & 17.96 & 0.973 & 15.18 & 0.09 & 0.974 & 16.92 & 1.089 & 0.973 \\
\hline
\end{tabular}

Note: Kd: distribution coefficient, a: capacity and b affinity coefficients of Langmuir isotherm; $\mathrm{k}$ and $\mathrm{n}$ are constants related to the capacity and affinity coefficients of Van Bemmelen-Freundlich isotherm

\section{Changes of the retained PTEs with ageing}

Values of the PTEs retained in soil (total minus soluble contents) were calculated and then presented graphically versus soil ageing. The outcome relations were fitted to five kinetic models i.e zero order reaction, first order reaction, power function, simple Elovich and parabolic diffusion. The calculated " $\mathrm{r}$ " " values and standard error of estimation (S.E.) are presented in Table 4. Based on the highest " $\mathrm{r}^{2}$ " and lowest "S.E." values, the power function and the parabolic diffusion seemed to be the best models fittings for the kinetics of PTEs retention in the studied Typic Torripsamment within the different soil layers. Such models probably indicate that the kinetics of PTEs retention is controlled by the diffusion process which affects strongly the redistribution and reactivity of PTEs in soil (Han et al., 2001) beside of the transformation of PTEs into the organic bound fractions (Han and Banin, 1999). Retention coefficient rates (calculated from the "Power function kinetic model) and diffusion rate constant (calculated from the "Parabolic diffusion kinetic model) are presented in Table 5 and Figs 8 and 9.

Results shown in Table 5 reveal that the values of the retention coefficient rates (calculated for the "Power function kinetic model") increased with increasing soil depth; whereas, the diffusion rate constant decreased with increasing the depth. Probably, soil compaction within the sub-surface soil layers brought soil particles close together (Gao et al., 2016), thus the water infiltration decreased (Epron et al., 2016) and consequently the diffusion rate constant of PTEs decreased. On the other hand, SOM decreased with soil depth (Fig. 2); therefore, the affinity of SOM to form organometal complexes decreased noticeably (Kleber et al., 2015). Generally, the retention coefficient rates among $\mathrm{Ni}, \mathrm{Cd}$ and $\mathrm{Cu}$ seemed to be close to each other, while slightly varied among $\mathrm{Co}$, $\mathrm{Zn}$ and $\mathrm{Cu}$. In this concern, $\mathrm{Cu}$ has high affinity to form organo-metal complexes (Lookwood et al., 2015) mainly with low molecular weight organic matter (Calace et al., 2001) and this might result in formation of soluble complexes (Zhou and Wong, 2001; Clemente et al., 2006) whereas $\mathrm{Cd}$ is mainly adsorbed by high molecular weight organic matter (Calace et al., 2001). Moreover, Ni complexes are less labile than $\mathrm{Cd}$ or $\mathrm{Zn}$ complexes (Welikala et al, 2018). The lowest diffusion rate constant was recorded for $\mathrm{Cd}$ while the highest ones were recorded for $\mathrm{Zn}$ and $\mathrm{Pb}$. This might be attributed to the relatively low concentrations of $\mathrm{Cd}$ in soil while those of $\mathrm{Zn}$ and $\mathrm{Pb}$ were the highest among the studied ones. 
TABLE 4. Values of coefficient of determination $\left(r^{2}\right)$ and standard error of estimation (S.E.) for the kinetic models

\begin{tabular}{|c|c|c|c|c|c|c|c|c|c|c|c|}
\hline & \multirow{2}{*}{$\begin{array}{l}\text { Soil } \\
\text { layer, } \\
\mathrm{cm}\end{array}$} & \multicolumn{2}{|c|}{$\begin{array}{c}\text { Zero Order } \\
\text { Reaction }\end{array}$} & \multicolumn{2}{|c|}{$\begin{array}{c}\text { First Order } \\
\text { Reaction }\end{array}$} & \multicolumn{2}{|c|}{ Power Function } & \multicolumn{2}{|c|}{ Simple Elovich } & \multicolumn{2}{|c|}{$\begin{array}{l}\text { Parabolic } \\
\text { Diffusion }\end{array}$} \\
\hline & & $r^{2}$ & S.E. & $\mathrm{r}^{2}$ & S.E. & $\mathrm{r}^{2}$ & S.E. & $\mathrm{r}^{2}$ & S.E. & $\mathrm{r}^{2}$ & S.E. \\
\hline & $0-30$ & 0.795 & 14.965 & 0.518 & 0.529 & 0.952 & 4.770 & 0.807 & 14.281 & 0.966 & 5.980 \\
\hline \multirow[t]{3}{*}{$\mathrm{Ni}$} & $30-60$ & 0.862 & 10.124 & 0.573 & 0.512 & 0.963 & 5.202 & 0.732 & 14.092 & 0.973 & 4.184 \\
\hline & $60-120$ & 0.884 & 7.435 & 0.597 & 0.504 & 0.973 & 5.307 & 0.691 & 12.134 & 0.970 & 3.759 \\
\hline & $0-30$ & 0.944 & 16.215 & 0.736 & 0.459 & 0.933 & 2.082 & 0.547 & 46.117 & 0.971 & 11.626 \\
\hline \multirow[t]{3}{*}{$\mathrm{Pb}$} & $30-60$ & 0.867 & 14.909 & 0.678 & 0.423 & 0.889 & 13.587 & 0.577 & 26.551 & 0.913 & 12.066 \\
\hline & $60-120$ & 0.916 & 2.329 & 0.815 & 0.383 & 0.975 & 10.772 & 0.439 & 6.010 & 0.909 & 2.415 \\
\hline & $0-30$ & 0.797 & 0.448 & 0.520 & 0564 & 0.934 & 0.241 & 0.779 & 0.470 & 0.962 & 0.195 \\
\hline \multirow[t]{3}{*}{$\mathrm{Cd}$} & $30-60$ & 0.861 & 0.349 & 0.629 & 0.508 & 0.938 & 0.232 & 0.634 & 0.567 & 0.945 & 0.936 \\
\hline & $60-120$ & 0.859 & 0.350 & 0.653 & 0.579 & 0.939 & 0.174 & 0.579 & 0.604 & 0.939 & 0.230 \\
\hline & $0-30$ & 0.949 & 2.863 & 0.597 & 0.848 & 0.992 & 1.151 & 0.567 & 8.371 & 0.982 & 1.690 \\
\hline \multirow[t]{3}{*}{$\mathrm{Co}$} & $30-60$ & 0.956 & 0.948 & 0.635 & 0.905 & 0.972 & 1.913 & 0.489 & 8.132 & 0.943 & 2.719 \\
\hline & $60-120$ & 0.963 & 1.992 & 0.675 & 0.905 & 0.964 & 1.960 & 0.428 & 7.845 & 0.905 & 3.1911 \\
\hline & $0-30$ & 0.882 & 71.962 & 0.684 & 0.871 & 0.951 & 19.652 & 0.460 & 153.732 & 0.914 & 61.398 \\
\hline \multirow[t]{3}{*}{$\mathrm{Zn}$} & $30-60$ & 0.968 & 30.414 & 0.772 & 0.819 & 0.969 & 29.713 & 0.385 & 132.778 & 0.950 & 52.675 \\
\hline & $60-120$ & 0.950 & 19.661 & 0.807 & 0.723 & 0.927 & 56.731 & 0.353 & 71.019 & 0.936 & 30.983 \\
\hline & $0-30$ & 0.797 & 17.783 & 0.492 & 0.705 & 0.958 & 8.142 & 0.747 & 19.869 & 0.946 & 9.175 \\
\hline \multirow[t]{2}{*}{$\mathrm{Cu}$} & $30-60$ & 0.886 & 8.967 & 0.562 & 0.583 & 0.970 & 4.600 & 0.707 & 14.372 & 0.979 & 3.838 \\
\hline & $60-120$ & 0.871 & 7.194 & 0.528 & 0.651 & 0.954 & 4.295 & 0.702 & 10.917 & 0.960 & 3.998 \\
\hline
\end{tabular}

TABLE 5. The calculated parameters of the best fitting kinetic models of PTEs sorption on Typic Torriorthent soil

\begin{tabular}{|c|c|c|c|c|c|c|}
\hline & \multicolumn{6}{|c|}{ Power Function model “ $b$ " (sorption rate coefficient $\left(\mu g \cdot g^{-1}\right)^{-1}$} \\
\hline $0-30$ & 0.299 & 0.435 & 0.322 & 0.607 & 0.688 & 0.355 \\
\hline $30-60$ & 0.356 & 0.551 & 0.428 & 0.731 & 0.942 & 0.395 \\
\hline $60-120$ & 0.387 & 0.632 & 0.501 & 0.877 & 0.950 & 0.397 \\
\hline $0-30$ & 9.996 & 21.147 & 0.305 & 3.945 & 62.673 & 12.021 \\
\hline $30-60$ & 8.415 & 12.205 & 0.285 & 3.459 & 50.354 & 8.218 \\
\hline $60-120$ & 0.674 & 2.395 & 0.283 & 3.089 & 25.885 & 6.135 \\
\hline
\end{tabular}



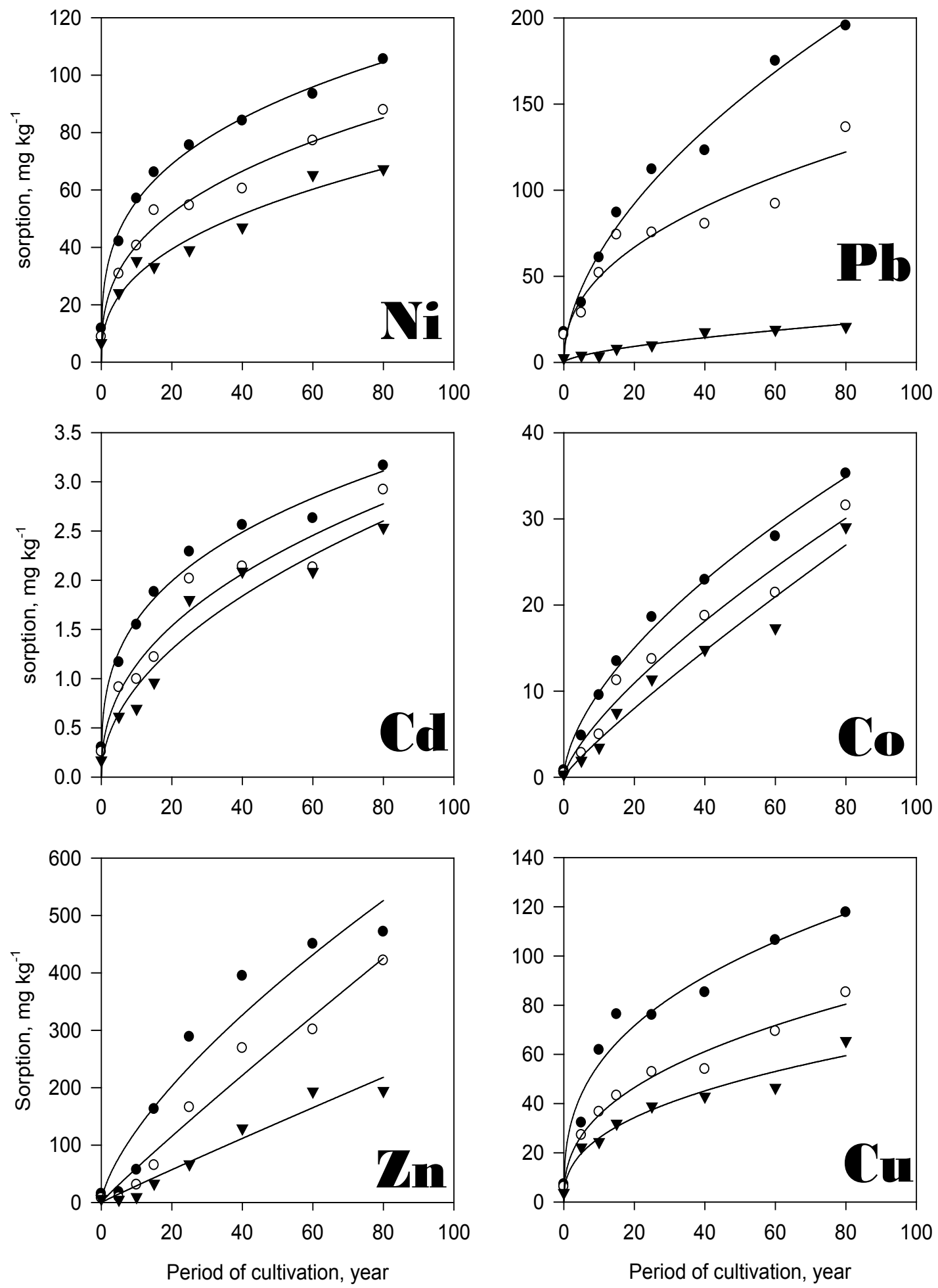

$\begin{array}{ll}\text { - } & 0-30 \mathrm{~cm} \\ \text { - } & 30-60 \mathrm{~cm} \\ \text { v } & 60-120 \mathrm{~cm}\end{array}$

Fig. 8. The power function fittings for the kinetics of heavy metal sorption in Typic Torriorthent soil: $0-30 \mathrm{~cm}(\bullet)$, $30-60 \mathrm{~cm}(\mathrm{)})$ and $60-120 \mathrm{~cm}(\nabla)$ 

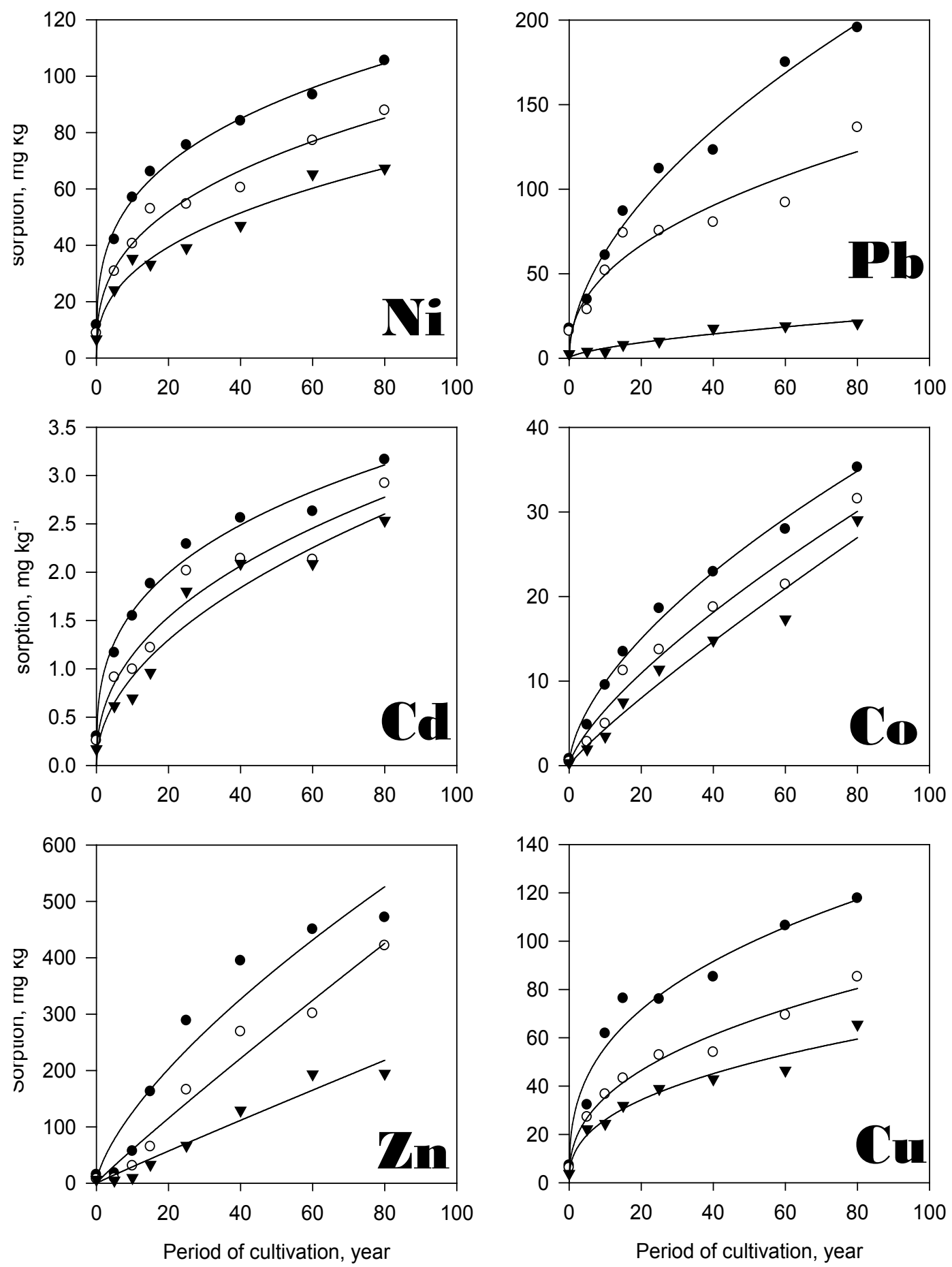

- $0-30 \mathrm{~cm}$

○ $30-60 \mathrm{~cm}$

v $60-120 \mathrm{~cm}$

Fig. 9. The parabolic diffusion fittings for the kinetics of heavy metal retention by the Typic Torriorthent soil: $0-30 \mathrm{~cm}(\bullet), 30-60 \mathrm{~cm}(\mathrm{)})$ and $60-120 \mathrm{~cm}(\nabla)$ 
Results of the correlations presented in Table 6 indicate that both the soluble and total concentrations of PTEs were significantly correlated with each of the organic matter content in soil and soil CEC. This might take place because of the functional groups of SOM which bind preferentially PTEs e.g. $\mathrm{Cu}$ and $\mathrm{Cd}$ (Lo et al., 2008). Similar results indicate that $\mathrm{Zn}$ (Kidd et al., 2007), $\mathrm{Cu}$, Ni (Yin et al., 2002; Ashworth and Alloway, 2004; Kahapanagiotis et al., 2008), $\mathrm{Pb}$ and $\mathrm{Cd}$ (Weng et al., 2002; Gondar et al., 2006) were closely related with the soil content of organic matter. The obtained results also reveal that the soluble contents of the studied metals were significantly correlated with their total contents in soil. These results agree with those of Gray and Mclaren (2006) who found that the solubility of PTEs in soil depends on each of SOM content and the total contents of PTEs themselves. It is worthy to mention that the soluble concentrations of PTEs were significantly correlated with each other. This probably occurred because the factors affecting the solubility of these PTEs are almost the same.

\section{Conclusion}

Soil organic matter plays significant roles in improving soil fertility; however it also increases the level of soil pollution with the potentially toxic elements (PTEs) especially in Typic Torriorthent soil. These organic residues stabilize PTEs in soil mainly within the surface soil layer $(0-30 \mathrm{~cm})$. Thus, there is no wonder to find out that the total and soluble concentrations of these metals in soil were significantly correlated with the SOM. It seems that the sorption of these metals took place via one molecule thickness and followed Langmuir isotherm model. The diffusion of PTEs in soil seemed to be a rate limiting step against PTEs retention versus soil ageing. Therefore, soil fertility and future use of sewage water in irrigation appears to be dependent on not only the PTEs contents of the irrigation water but also the effect of both PTE itself together with the soil properties specially the organic matter content and CEC on the transformations of the PTEs among the soluble and retained forms with ageing.

Acknowledgement: The authors would like to express their deep thanks to Prof. Dr. Hassan H. Abbas, Soils and Water Department, Benha University, Egypt for his help and valuable feedback on this manuscript.

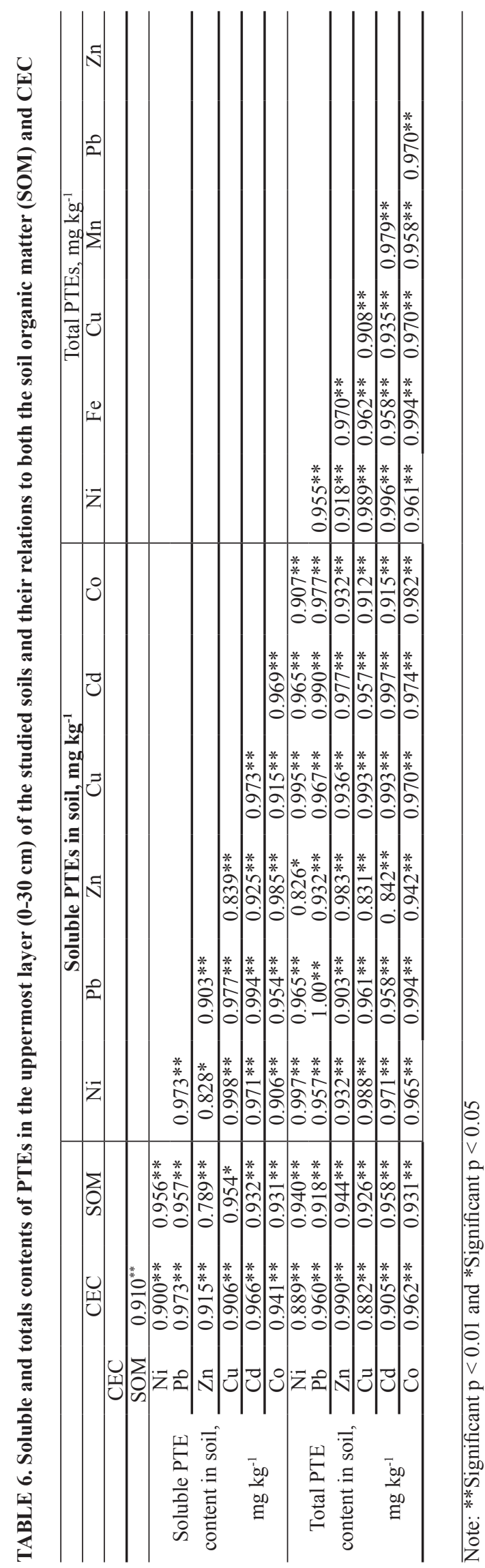

Egypt. J. Soil Sci. 58, No. 3 ( 2018) 


\section{References}

Abbas (2013) Kinetics of zinc ageing in Typic Torriorthent and Typic Haplocalcid soils. Egypt. J. Soil Sci, 53 (3), 413- 428. https://doi. org/10.21608/EJSS.2013.176

Abbas, M.H.H. and Abdelhafez, A.A. (2014) Role of EDTA in arsenic mobilization and its uptake by maize grown on an As-polluted soil. Chemosphere, 90, 588-594. http://dx.doi. org/10.1016/j.chemosphere.2012.08.042

Abbas, M.H.H. and Salem, H.M. (2011) Kinetics of iron retention by Typic Torriorthent and Typic Haplocalcid soils supplied with some micronutrients. Annals of Agric. Sci. Moshtohor 49, 301-311.

Abdelhafez, A. A., Abbas, H.H., Abd $\square$ El $\square$ Aal, R.S., Kandil, N.F., Li, J. and Mahmoud, W. (2012) Environmental and Health Impacts of Successive Mineral Fertilization in Egypt. Clean Soil Air Water, 40, 356-363. http://dx.doi.org/10.1002/ clen.201100151

Abdelhafez, A.A., Abbas, M.H.H. and Attia, T.M.S. (2015) Environmental monitoring of heavymetals status and human health risk assessment in the soil of Sahl El-Hessania area, Egypt. Pol J Environ Stud 24 (2), 459-467

Abdelhafez, A.A., Abbas, M.H.H., Attia, T.M.S., El Bably, W. and Mahrous, S.E. (2018) Mineralization of organic carbon and nitrogen in semi-arid soils under organic and inorganic fertilization, Environmental Technology \& Innovation, 9, 243-253, https://doi.org/10.1016/j. eti.2017.12.011.

Abdel-Shafy, H.I. and Abdel-Sabour, M.F. (2006) Wastewater reuse for irrigation on the desert sandy soil of Egypt: Long-term effect. In: Hlavinek P., Kukharchyk T., Marsalek J., Mahrikova I. (Ed.) Integrated Urban Water Resources Management. NATO Security through Science Series. Springer, Dordrecht. https://doi. org/10.1007/1-4020-4685-5_31

Abo el Abas, Y.M. (2004) Distribution pattern of some inorganic pollutants in groundwater and soil of a sewage farm at NE-Cairo/Egypt. In F. Zereini and W. Jaeschke. Water in the Middle East and in North Africa. Springer-Verlag Berlin Heidelberg pp: 191-203. https://doi. org/10.1007/978-3-662-10866-6
Aikpokpodion, P.E., Lajide, L. and Aiyesanmi, A.F. (2013) Characterization of heavy metal fractions in agricultural soils using sequential extraction technique. WJAS 9 (1), 45-52. https://doi. org/10.5829/idosi.wjas.2013.9.1.1119

Alloway B.J. (2013) Sources of Heavy Metals and Metalloids in Soils. In: Alloway B. (eds) Heavy Metals in Soils. Environmental Pollution, vol 22. Springer, Dordrecht. https://doi. org/10.1007/978-94-007-4470-7_2

Almås, A R., McBride, B.M. and Singh, B.R. (2000) Solubility and lability of cadmium and zinc in two soils treated with organic matter. Soil Science, 167 (3), 250-259. https://doi. org/10.1097/00010694-200003000-00007

Ashworth, D.J., and Alloway, B.J. (2004) Soil mobility of sewage sludge-derived dissolved organic matter, copper, nickel and zinc, Environ. Pollut, 127 (1), 137-144, https://doi.org/10.1016/ S0269-7491(03)00237-9.

Ashworth, D. J. and Alloway, B. J. (2008) Influence of Dissolved Organic Matter on the Solubility of Heavy Metals in Sewage $\square$ Sludge $\square$ Amended Soils, Commun Soil Sci Plant Anal, 39 (3-4), 538-550, https://doi. org/10.1080/00103620701826787

Ayers, R.S. and Westcot, D.W. (1994) Water quality for agriculture. FAO irrigation and drainage paper 29 Rev 1. http://www.fao.org/DOCREP/003/ T0234E/T0234E06.htm\#ch5.5.2

Blume, H.-P. and Brümmer, G. (1991) Prediction of heavy metal behavior in soil by means of simple field tests, Ecotox Environ. Safe, 22 (2), 164-174, https://doi.org/10.1016/0147-6513(91)90056-U.

Bolan N. S. and Duraisamy, V.P. (2003) Role of inorganic and organic soil amendments on immobilisation and phytoavailability of heavy metals: a review involving specific case studies. Soil Research, 41, 533-555. https://doi. org/10.1071/SR02122

Calace, N., Liberatori, A., Petronio, B.M. and Pietroletti, M. (2001) Characteristics of different molecular weight fractions of organic matter in landfill leachate and their role in soil sorption of heavy metals, Environ. Pollut, 113 (3), 331-339, https://doi.org/10.1016/S0269. 7491(00)00186-X.

Chen, X. (2015) Modeling of Experimental Adsorption Isotherm Data. Information, 6 (1), 
14-22. https://doi.org/10.3390/info6010014

Ciavatta, C., Govi, M., Simoni, A. and Sequi, P. (1993) Evaluation of heavy metals during stabilization of organic matter in compost produced with municipal solid wastes, Bioresource Technol, 43 (2), 147-153, https://doi.org/10.1016/09608524(93)90174-A.

Clemente, R., Escolar, Á. and Bernal, M.P. (2006) Heavy metals fractionation and organic matter mineralization in contaminated calcareous soil amended with organic materials, Bioresource Technol, 97 (15), 1894-1901, https://doi. org/10.1016/j.biortech.2005.08.018.

Diagboya, P.N., Olu-Owolabi, B.I. and Adebowale, K.O. (2015) Effects of time, soil organic matter, and iron oxides on the relative retention and redistribution of lead, cadmium, and copper on soils. Environ Sci Pollut Res 22, 10331-10339. https://doi.org/10.1007/s11356-015-4241-0

Ebong, G.A., Dan, E.U., Inam, E. and Offiong, N.O. (2018) Total concentration, speciation, source identification and associated health implications of trace metals in Lemna dumpsite soil, Calabar, Nigeria. Journal of King Saud University-Science. https://doi.org/10.1016/j.jksus.2018.01.005

Elbana, T.A., Ramadan, M.A., Gaber, H.M., Bahnassy, M.H., Kishk, F.M., Selim, H.M. (2013) Heavy metals accumulation and spatial distribution in long term wastewater irrigated soils, J Environ Chem Eng. 1 (4), 925-933, https://doi.org/10.1016/j.jece.2013.08.005.

Elgala, A.M., Elsharawy, M.A.O. and Elbordiny, M.M. (2003) Impact of sewage water used for irrigation on soil characteristics and heavy metals composition of some grown crops. Egypt. J. Soil Sci. 43 (3), 405-419

El-Hassanin, A.S., Labib, T.M. and Dobal, A.T. (1993) Potential Pb, Cd, Zn and B contamination of sandy soils after different irrigation periods with sewage effluent. Water Air Soil Pollut. 66, 239-249. https://doi.org/10.1007/bf00479848

El-Motaium, R., Hashim, M.-S. and Caria, G. (2009) Fate and Behavior of Toxic Organic Pollutants in Plant, Soil and Irradiated Sewage Sludge. In: Bahadir, A. and Duca, G. (Ed.), The Role Of Ecological Chemistry In Pollution Research And Sustainable Development. Springer Netherlands, pp.209-219. http://dx.doi.org/10.1007/978-90481-2903-4_22
Epron, D., Plain, C., Ndiaye, F.-K., Bonnaud, P., Pasquier, C. and Ranger, J. (2016) Effects of compaction by heavy machine traffic on soil fluxes of methane and carbon dioxide in a temperate broadleaved forest, Forest Ecol Manag, 382, 1-9, https://doi.org/10.1016/j.foreco.2016.09.037.

Farid, I.M., Abbas, M.H.H., Beheiry, G.Gh.S. and Elcossy, S.A.E. (2014). Implications of organic amendments and tillage of a sandy soil on its physical properties and $\mathrm{C}$-sequestration as well as its productivity of wheat and maize grown thereon. Egypt. J. Soil Sci, 54 (2), 177-194. https://doi.org/10.21608/ejss.2014.132

Gao, W., Hodgkinson, L., Jin, K., Watts, C.W., Ashton, R. W., Shen, J., Ren, T., Dodd, I.C., Binley, A., Phillips, A.L., Hedden, P., Hawkesford, M.J. and Whalley, W.R. (2016) Deep roots and soil structure. Plant Cell Environ., 39, 1662-1668. https://doi.org/10.1111/pce.12684.

Gondar, D., López, R., Fiol, S., Antelo, J.M. and Arce, F. (2006) Cadmium, lead, and copper binding to humic acid and fulvic acid extracted from an ombrotrophic peat bog, Geoderma, 135, 196-203, https://doi.org/10.1016/j. geoderma.2005.12.003.

Gray, C.W. and Mclaren, R.G. (2006) Soil factors affecting heavy metal solubility in some New Zealand soils. Water Air Soil Pollut. 175, 3-14. https://doi.org/10.1007/s11270-005-9045-2

Greger, M. (2005) Metal availability, uptake, transport and accumulation in plants. In M.N.V. Prasad (Ed.) Heavy Metal Stress In Plants: From Biomolecules To Ecosystems, Springer-Verlag, Berlin, pp. 1-27. https://doi.org/10.1007/978-3662-07743-6

Guo, T., Lou, C., Zhai, W., Tang, X., Hashmi, M. Z., Murtaza, R., Li, Y., Liu, X. and Xu, J. (2018) Increased occurrence of heavy metals, antibiotics and resistance genes in surface soil after longterm application of manure, Sci Total Environ, 635, 995-1003, https://doi.org/10.1016/j. scitotenv.2018.04.194.

Gustafsson, J.P., Pechová, P. and Berggren, D. (2003) Modeling metal binding to soils: The role of natural organic matter. Environ Sci. Technol. 37 (12), 2767-2774. https://doi.org/10.1021/ es026249t

Han, F.X. and Banin, A. (1999) Long-term 
transformation and redistribution of potentially toxic heavy metals in arid-zone soils: II. Incubation at the field capacity moisture content. Water Air Soil Pollut. 114, 221-250. https://doi. org/10.1023/A:1005006801650

Han, F. X., Banin, A. and Triplett, G.B. (2001) Redistribution of heavy metals in arid-zone soils under a wetting-drying cycle soil moisture regime. Soil Science, 166 (1), 18-28. https://doi. org/10.1097/00010694-200101000-00005

Hashim, T., Abbas, H.H., Farid, I.M., El-Husseiny, O. and Abbas, M.H.H. (2017) Accumulation of some heavy metals in plants and soils adjacent to Cairo - Alexandria agricultural highway. Egypt. J Soil Sci. 57 (2), 215-232. https://doi. org/10.21608/ejss.2016.281.1047

Ibrahim, Z.K., Abdel-Hameed, A.H., Farid, I.M., Abbas, M.H.H. and Abbas, H.H. (2016) Implications of using Belbais drain water for irrigation of wheat in the North East region of Egypt. J. Soil Sci. and Agric End., Mansoura University., 7 (3),1-12

Jobbágy, E. G. and Jackson, R.B. (2000) The vertical distribution of soil organic carbon and its relation to climate and vegetation. Ecol. Appl., 10, 423-436. https://doi.org/10.1890/10510761(2000)010[0423:TVDOSO]2.0.CO;2

Kabata-Pendias, A. and Pendias, H. (2001) Trace Elements in Soils and Plants. Third edition, CRC Press LLC, Florida.

Kahapanagiotis, N.K., Steheitt, R. M. and Lester, J. N. (2008) Heavy metal complexation in sludge $\square$ amended soil. The role of organic matter in metal retention, Environ Technol., 12 (12), 1107-1116, https://doi.org/10.1080/09593339109385111

Kalbitz, K. and Wennrich, R. (1998) Mobilization of heavy metals and arsenic in polluted wetland soils and its dependence on dissolved organic matter, Sci. Total Environ. 209 (1), 27-39, https://doi. org/10.1016/S0048-9697(97)00302-1.

Khan, S., Cao, Q., Zheng, Y.M., Huang, Y.Z. and Zhu, Y.G. (2008) Health risks of heavy metals in contaminated soils and food crops irrigated with wastewater in Beijing, China, Environ. Pollut., 152 (3), 686-692, https://doi.org/10.1016/j. envpol.2007.06.056.

Kidd, P.S., Domínguez-Rodríguez, M.J., Díez, J. and
Monterroso, C. (2007) Bioavailability and plant accumulation of heavy metals and phosphorus in agricultural soils amended by long-term application of sewage sludge, Chemosphere, 66 (8), 1458-1467, https://doi.org/10.1016/j. chemosphere.2006.09.007.

Kleber, M., Eusterhues, K., Keiluweit, M., Mikutta, C., Mikutta, R. and Nico, P.S. (2015) Chapter One - Mineral-Organic Associations: Formation, Properties, and Relevance in Soil Environments, In: D. L. Sparks, Adv Agron, Academic Press, Volume 130, pp 1-140, https://doi.org/10.1016/ bs.agron.2014.10.005

Klute, A. (1986) Part 1. Physical and mineralogical methods. ASA-SSSA-Agronomy, Madison, Wisconsin USA.

Kunhikrishnan, A., Choppala, G., Seshadri, B., Wijesekara, H., Bolan, N.S., Mbene, K. and Kim, W.-I. (2017) Impact of wastewater derived dissolved organic carbon on reduction, mobility, and bioavailability of $\mathrm{As}(\mathrm{V})$ and $\mathrm{Cr}$ (VI) in contaminated soils, J. Environ Manage., 186 (2), 183-191, https://doi.org/10.1016/j. jenvman.2016.08.020.

Lacatusu. R. (2000) Appraising levels of soil contamination and pollution with heavy metals. In: Heinike, H.J., Eckselman, W., Thomasson, A.J., Jones, R.J.A., Montanarella, L. and Buckeley, B. (Ed.). Land Information Systems For Planning The Sustainable Use Of Land Resources. European Soil Bureau Research Report, pp. 393 - 402

Lair, G.J., Gerzabek, M.H. and Haberhauer, G. (2007) Sorption of heavy metals on organic and inorganic soil constituents. Environ Chem Lett 5, 23-27. https://doi.org/10.1007/s10311-0060059-9

Lehmann, J. and Kleber, M. (2015) The contentious nature of soil organic matter. Nature, 528, 60-68. https://doi.org/10.1038/nature16069

Lindsay, W.L. (1979) Chemical Equilibria In Soil. John Wiley \& Sons, New York.

Lo, K. S. L., Yang, W. F. and Lin, Y. C. (2008) Effects of organic matter on the specific adsorption of heavy metals by soil, Toxicol. Environ. Chem., 34, 2-4, 139-153, https://doi. org/10.1080/02772249209357787 
Loffredo, E. and Senesi, N. (2006) Fate of anthropogenic organic pollutants in soils with emphasis on adsorption/desorption processes of endocrine disruptor compounds. Pure Appl. Chem. 78 (5), 947-961. https://doi.org/10.1351/ pac20067805094

Lookwood, C.L., Stewart, D. I., Mortimer, R. J. G. , Mayes, W. M., Jarvis, A. P., Gruiz, K. and Burke, I. T. (2015) Leaching of copper and nickel in soil-water systems contaminated by bauxite residue (red mud) from Ajka, Hungary: the importance of soil organic matter. Environ Sci Pollut Res, 22, 10800-10810 https://doi. org/10.1007/s11356-015-4282-4

Machmuller, M.B., Kramer, M. G., Cyle, T. K., Hill, N., Hancock, D. and Thompson, A. (2015) Emerging land use practices rapidly increase soil organic matter. Nat Commun. 6, Article number: 6995. https://doi.org/10.1038/ncomms7995

Mapanda, F., Mangwayana, E.N., Nyamangara, J. and Giller, K.E. (2005) The effect of long-term irrigation using wastewater on heavy metal contents of soils under vegetables in Harare, Zimbabwe, Agr Ecosyst Environ, 107, (2-3), 151165, https://doi.org/10.1016/j.agee.2004.11.005.

Mohamed, I., Ali, M., Ahmed, N., Abbas, M.H.H., Abdelsalam, M., Azab, A., Raleve, D. and Fang, C. (2018) Cow manure-loaded biochar changes $\mathrm{Cd}$ fractionation and phytotoxicity potential for wheat in a natural acidic contaminated soil, Ecotox Environ. Safe, 162, 348-353, https://doi. org/10.1016/j.ecoenv.2018.06.065.

Nelson, D. W. and Sommers, L. E. (1996) Total Carbon, Organic Carbon, and Organic Matter In: D.L. Sparks, A.L. Page, P.A. Helmke, R.H. Loeppert, P.N. Soltanpour, M.A. Tabatabai, C.T. Johnston and M.E. Sumner. SSSA Book Series, Methods of Soil Analysis Part 3-Chemical Methods, 5.3, 961-1010. https://doi.org/10.2136/ sssabookser5.3.c34

Nicholson, F.A., Smith, S.R., Alloway, B.J., Carlton-Smith, C. and Chambers, B.J. (2003) An inventory of heavy metals inputs to agricultural soils in England and Wales, Sci. Total Environ., 311 (1-3), 205-219, https://doi.org/10.1016/ S0048-9697(03)00139-6.

Peng, J.-f., Song, Y.-h., Yuan, P., Cui, X.-y., and Qiu, G.-1. (2009) The remediation of heavy metals contaminated sediment, J. Hazard Mater., 161 (2-3), 633-640, https://doi.org/10.1016/j. jhazmat.2008.04.061.

Refaey, Y., Jansen, B., Parsons, J.R., de Voogt, P., Bagnis, S., Markus, A., El-Shater, A., ElHaddad, A. and Kalbitz, K. (2017) Effects of clay minerals, hydroxides, and timing of dissolved organic matter addition on the competitive sorption of copper, nickel, and zinc: A column experiment, J. Environ Manage, 187, 273-285, https://doi.org/10.1016/j.jenvman.2016.11.056.

Ren, Z. -L., Tella, M., Bravin, M.N., Comans, R.N.J., Dai, J., Garnier, J.-M., Sivry, Y., Doelsch, E., Straathof, A. and Benedetti, M.F. (2015) Effect of dissolved organic matter composition on metal speciation in soil solutions, Chemical Geology, 398, 61-69, https://doi.org/10.1016/j. chemgeo.2015.01.020

Reyhanitabar, A. and Gilkes, R.J. (2010) Kinetics of DTPA extraction of zinc from calcareous soils. Geoderma 154, 289-293. https://doi. org/10.1016/j.geoderma.2009.10.016

Rikta, S.Y., Tareq, S.M. and Uddin, M.K. (2018) Toxic metals $(\mathrm{Ni} 2+, \mathrm{Pb} 2+, \mathrm{Hg} 2+)$ binding affinity of dissolved organic matter (DOM) derived from different ages municipal landfill leachate. Appl Water Sci. 8, 5. https://doi.org/10.1007/s13201018-0642-9

Rodeghiero, M., Heinemeyer, A., Schrumpf, M. and Bellamy, P. (2009) Determination of soil carbon stocks and changes. In: Kutsch, W.L., Bahn, M., Heinemeyer, A. (Ed.), Soil Carbon Dynamics: An Integrated Methedology. Cambridge University Press, Cambridge

Rowell D. (1994) Soil Science Methods And Applications. Longman Scientific \& Technical, Longman Group UK Ltd, Harlow, Essex, UK

Sahrawat, K.L., Kumar, G.R. and Rao, J.K. (2002) Evaluation of triacid and dry ashing procedures for determining potassium, calcium, magnesium, iron, zinc, manganese, and copper in plant materials. Comm. Soil Sci. Plant Anal. 33 (1-2), 95-102. https://doi.org/10.1081/CSS-120002380

Sparks, D.L. (1999) Soil Physical Chemistry, 2nd edition. CRC Press, LLC, Boca Raton

Sparks, D.L., Page, A.L., Helmke, P.A., Loeppert, R.H., Soltanpour, P.N., Tabatabai, M.A., Johnston, C.T. and Sumner, M.E. (1996) Methods of Soil Analysis Part 3-Chemical Methods, 5.3, SSSA Book Series, Madison, WI.

Egypt. J. Soil Sci. 58, No. 3 ( 2018) 
Sposito, G. (2008) The Chemistry of Soils, 2nd ed., Oxford University Press, Inc., New York.

Strawn, D. G., and Sparks, D. L. (2000) Effects of Soil Organic Matter on the Kinetics and Mechanisms of $\mathrm{Pb}$ (II) Sorption and Desorption in Soil. Soil Sci. Soc. Am. J. 64, 144-156. https:// doi.org/10.2136/sssaj2000.641144x

Su, Y., Wang, J., Peng, S.C., Yue, Z.B., Chen, T.H. and Jin, J. (2010) Rice straw and sewage sludge as carbon sources for sulfate-reducing bacteria treating acid mine drainage. Huan Jing Ke Xue 31, 1858-1863.

Tiberg, C., Sjöstedt, C. and Gustafsson, J.P. (2018) Metal sorption to Spodosol Bs horizons: Organic matter complexes predominate, Chemosphere, 196, 556-565, https://doi.org/10.1016/j. chemosphere.2018.01.004.

Wang, F., Pan, Y., Cai, P., Guo, T. and Xiao, H. (2017) Single and binary adsorption of heavy metal ions from aqueous solutions using sugarcane cellulose-based adsorbent, Bioresource Technol, 241, 482-490, https://doi. org/10.1016/j.biortech.2017.05.162.

Welikala, D., Hucker, C., Hartland, A., Robinson, B.H. and Lehto, N. J. (2018) Trace metal mobilization by organic soil amendments: insights gained from analyses of solid and solution phase complexation of cadmium, nickel and zinc, Chemosphere, 199, 684-693, https:// doi.org/10.1016/j.chemosphere.2018.02.069.

Wen, J., Li, Z., Luo, N., Huang, M., Yang, R. and Zeng, G. (2018) Investigating organic matter properties affecting the binding behavior of heavy metals in the rhizosphere of wetlands, Ecotox Environ. Safe, 162, 184-191, https://doi. org/10.1016/j.ecoenv.2018.06.083.
Weng,L., Temminghoff, E.J.M., Lofts, S., Tipping, E. and Van Riemsdijk, W.H. (2002) Complexation with dissolved organic matter and solubility control of heavy metals in a sandy soil. Environ Sci Technol. 36 (22), 4804-4810. https:// doi.org/10.1021/es0200084

Yin, Y., Impellitteri, C.A., You, S.-J. and Allen, H.E. (2002) The importance of organic matter distribution and extract soil:solution ratio on the desorption of heavy metals from soils, Sci. Total Environ., 287 (1-2), 107-119, https://doi. org/10.1016/S0048-9697(01)01000-2.

Yue, Y., Yao, Y., Lin, Q., Li, G., Zhao, X. (2017) The change of heavy metals fractions during hydrochar decomposition in soils amended with different municipal sewage sludge hydrochars. J Soils Sediments, 17, 763 -770. https://doi. org/10.1007/s11368-015-1312-2

Zaghloul, A.M., El-Dewiny, C. and Youssef, R.A. (2006) Distribution of lead and zinc metals in some Egyptian soils. J. Appl. Sci. Res. 2(5), 284289.

Zhou, L.X., and Wong, J.W.C. (2001) Effect of dissolved organic matter from sludge and sludge compost on soil copper sorption. J. Environ. Qual. 30, 878-883. https://doi.org/10.2134/ jeq2001.303878x

Zhou, Y.-F. and Haynes, R.J. (2010) Sorption of heavy metals by inorganic and organic components of solid wastes: Significance to use of wastes as low-cost adsorbents and immobilizing agents, Crit Rev Environ Sci Technol., 40(11), 909-977, https://doi.org/10.1080/10643380802586857

((Received 27/6/2018; accepted: $8 / 8 / 2018$ ) 
تداعيات الري طويل الاجل باستخدام المياه العادمة علي محتوي وحركية ادمصاص ايونات

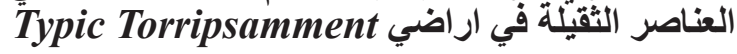

\author{
محمد حسن حمزة عباس، ومحمد أحمد بسيوني

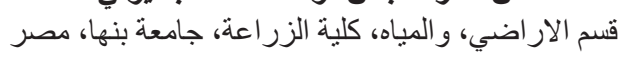

\begin{abstract}
يهذف هذا البحث إلي در اسة تداعيات الري باستخدام المياه العادمة (الغنية في محتو اها من المادة العضوية) علي

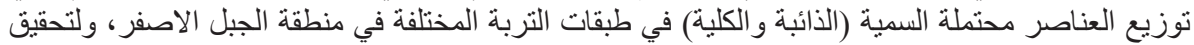

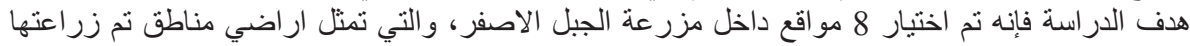

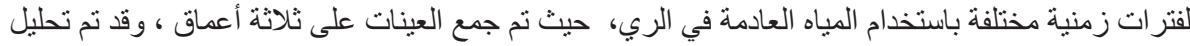

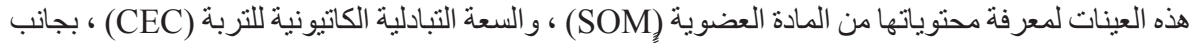

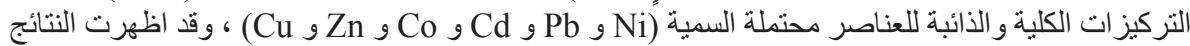

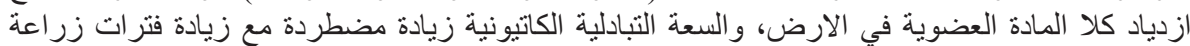

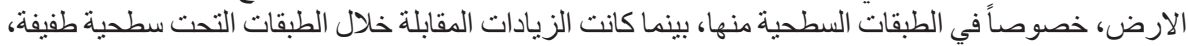

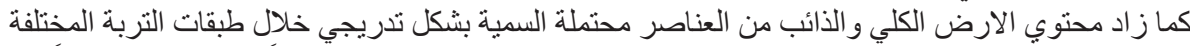

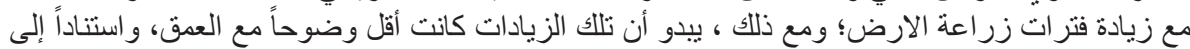

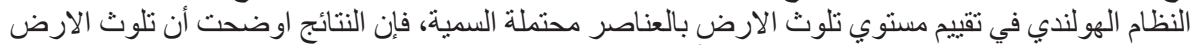

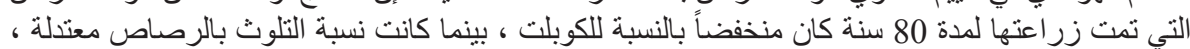

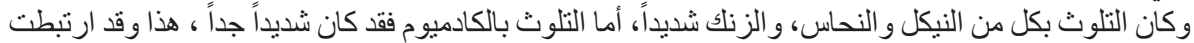

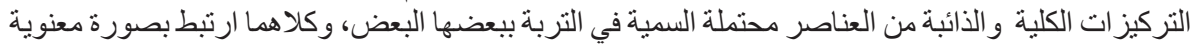

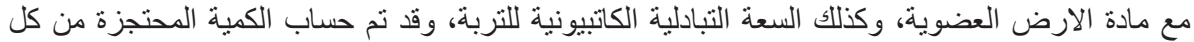

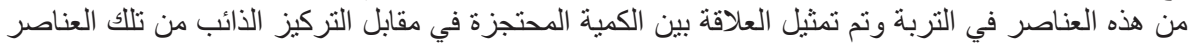

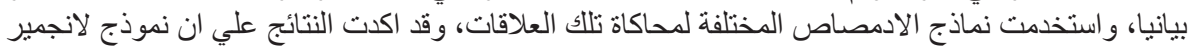
Langmuir

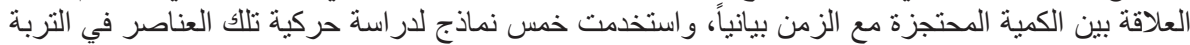

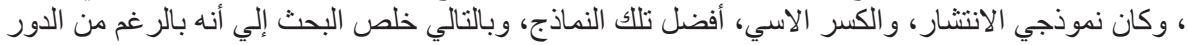

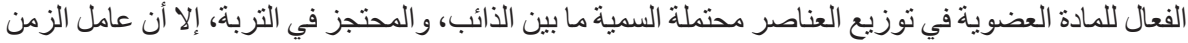

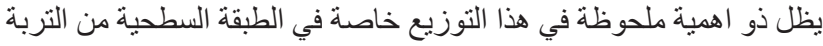

